\title{
The DNA methylation level against the background of the genome size and t-heterochromatin content in some species of the genus Secale $L$
}

\author{
Anna Kalinka ${ }^{1,2}$, Magdalena Achrem ${ }^{\text {Corresp., }}{ }^{1,2}$, Paulina Poter ${ }^{1}$ \\ 1 Department of Cell Biology, Faculty of Biology, University of Szczecin, Waska 13, 71-415 Szczecin, Poland \\ 2 Molecular Biology and Biotechnology Center, Faculty of Biology, University of Szczecin, Waska 13, 71-415 Szczecin, Poland \\ Corresponding Author: Magdalena Achrem \\ Email address: biolmagda@poczta.onet.pl
}

Methylation of cytosine in DNA is one of the most important epigenetic modifications in eukaryotes and plays a crucial role in the regulation of gene activity and the maintenance of genomic integrity. DNA methylation and other epigenetic mechanisms affect the development, differentiation or the response of plants to biotic and abiotic stress. This study compared the level of methylation of cytosines on a global (ELISA) and genomic scale (MSAP) between the species of the genus Secale. It was analyzed whether the interspecific variation of cytosine methylation was associated with the size of the genome (C-value) and the content of telomeric heterochromatin. MSAP analysis showed that $S$. sylvestre was the most distinct species among the studied rye taxa, however, the results clearly indicated that these differences were not statistically significant. The total methylation level of the studied loci was very similar in all taxa and ranged from $60 \%$ in $S$. strictum ssp. africanum to $66 \%$ in S. cereale ssp. segetale, which confirmed the lack of significant differences in the sequence methylation pattern between the pairs of rye taxa. The level of global cytosine methylation in the DNA was not significantly associated with the content of t-heterochromatin and did not overlap with the existing taxonomic rye relationships. The highest content of 5-methylcytosine was found in S. cereale ssp. segetale (83\%), while very low in S. strictum ssp. strictum (53\%), which was significantly different from the methylation state of all taxa, except for $S$. sylvestre. The other studied taxa of rye had a similar level of methylated cytosine ranging from $66.42 \%$ (S. vavilovii) to $74.41 \%$ in (S. cereale ssp. afghanicum). The results obtained in this study are evidence that the percentage of methylated cytosine cannot be inferred solely based on the genome size or t-heterochromatin. This is a significantly more complex issue. 
1 The DNA methylation level against the background of the genome size and t-

2 heterochromatin content in some species of the genus Secale $\mathrm{L}$.

3 Anna Kalinka ${ }^{1,2}$, Magdalena Achrem ${ }^{1,2}$, Paulina Poter ${ }^{1}$

$4{ }^{1}$ University of Szczecin, Faculty of Biology, Department of Cell Biology, Waska 13, 71- 415 Szczecin,

5 Poland;

$6{ }^{2}$ Molecular Biology and Biotechnology Center, Faculty of Biology, University of Szczecin, Wąska 13, 71-

7415 Szczecin, Poland

$8 \quad$ Anna Kalinka akali@op.pl

9 Magdalena Achrem biolmagda@poczta.onet.pl

10 Paulina Poter p.poter@op.pl

11 Corresponding author:

12 Magdalena Achrem e-mail: biolmagda@poczta.onet.pl

13 phone: +48914441523 


\section{Abstract}

15 Methylation of cytosine in DNA is one of the most important epigenetic modifications in 16 eukaryotes and plays a crucial role in the regulation of gene activity and the maintenance of 17 genomic integrity. DNA methylation and other epigenetic mechanisms affect the development, 18 differentiation or the response of plants to biotic and abiotic stress. This study compared the level 19 of methylation of cytosines on a global (ELISA) and genomic scale (MSAP) between the species 20 of the genus Secale. It was analyzed whether the interspecific variation of cytosine methylation 21 was associated with the size of the genome (C-value) and the content of telomeric

22 heterochromatin. MSAP analysis showed that $S$. sylvestre was the most distinct species among 23 the studied rye taxa, however, the results clearly indicated that these differences were not 24 statistically significant. The total methylation level of the studied loci was very similar in all taxa 25 and ranged from $60 \%$ in $S$. strictum ssp. africanum to $66 \%$ in $S$. cereale ssp. segetale, which 26 confirmed the lack of significant differences in the sequence methylation pattern between the

27 pairs of rye taxa. The level of global cytosine methylation in the DNA was not significantly 28 associated with the content of t-heterochromatin and did not overlap with the existing taxonomic 29 rye relationships. The highest content of 5-methylcytosine was found in S. cereale ssp. segetale 30 (83\%), while very low in S. strictum ssp. strictum (53\%), which was significantly different from

31 the methylation state of all taxa, except for $S$. sylvestre. The other studied taxa of rye had a 32 similar level of methylated cytosine ranging from $66.42 \%$ ( $S$. vavilovii) to $74.41 \%$ in (S. cereale 33 ssp. afghanicum).

34 The results obtained in this study are evidence that the percentage of methylated cytosine cannot 35 be inferred solely based on the genome size or t-heterochromatin. This is a significantly more 36 complex issue. 
INTRODUCTION

Among epigenetic mechanisms, DNA methylation, histone modifications, chromatin or

RNAi rearrangements can be distinguished, which are responsible for the regulation of gene expression and the maintenance of genomic integrity. All these mechanisms can affect the phenotype of the organism without altering the DNA sequence (Grant-Dowton \& Dickinson, 2005; Jablonka \& Raz, 2009; Hirsch, Baumberger \& Grossniklaus, 2013; Alonso et al., 2015). In plants, changes in the level of cytosine methylation may affect the viability, fertility, inbred status or herbicide resistance (Santo et al., 1990; Johannes et al., 2009; Verhoeven et al., 2010; Herrera \& Bazaga, 2011; Vergeer, Wagemaker \& Ouborg, 2012).

Epigenetic mechanisms, particularly through DNA methylation, may also affect macroevolution by the potential impact on diversification rate and speciation. In addition, methylated cytosines are more frequently mutated than the unmethylated ones (Nachman \& Crowell, 2000; Ossowski et al., 2010; Alonso et al., 2015). Therefore, methylation can influence the frequency of point mutations and favor the occurrence of evolutionary changes (McClintock, 1984; Gorelick, 2003). The analysis of the level of global methylation of cytosines is the first step in evaluating the role of this epigenetic mechanism in the evolution of non-model organisms

53 (Rozhon et al., 2008). Interspecific variation in the cytosine global methylation is not well understood, although some studies showed significant differences between species (Finnegan et al., 1998; Bender, 2004; Alonso et al., 2015). There is no information available whether interspecies differences in the level of cytosine global methylation are associated with changes resulting from their evolution, e.g., the size of the genome. The size of plant genome is a speciesspecific trait, and its enlargement in the course of evolution resulted primarily from an increase in the number of copies of repetitive sequences (Bennett \& Leitch, 2012; Leitch \& Leitch, 2013; Alonso et al,. 2015) thus, theoretically, one could expect an increase in the level of methylation. 
62 heterochromatin areas, such as telomeric, centromeric and pericentromeric regions (Li et al.,

63 2008; Zilberman et al., 2007) where high levels of DNA methylation are observed, while they are

64 lower in the euchromatin. Transposable elements (TEs), the amplification of which may lead to

65 an increase in the size of the genome are such repeated sequences. Usually they are highly

66 methylated, thus they can not be active, which protects genome integrity (Fujimoto et al., 2008;

67 Sasaki et al., 2011; Kawanabe et al., 2012). Under stress conditions, silencing of TEs can be

68 abrogated, they can transpose, which especially in the case of retroelements can cause a

69 significant increase in the number of copies in the genome. After stress cessation, they are

70 silenced again. If a TE is inserted in the coding region, it can inhibit the expression of a given

71 gene (Kakutani, 2002; Tsukahara, 2009) or neighboring genes (Fernandez et al., 2010; Fujimoto

72 et al., 2006; Hollister \& Gaut, 2009; Lippman et al., 2004; Naito et al., 2009), because the

73 heterochromatin state can spread to adjacent regions. Through this mechanism, genome expands

74 and the level of global methylation changes (Bird, 1995; Federoff, 2000; Federoff, 2012; Grover

$75 \&$ Wendel, 2010). Since the distribution of transposable elements varies even among closely

76 related species, it can be assumed that TE polymorphisms affect the epigenetic variability (Saze

77 \& Kakutani, 2007; Kawanabe et al., 2012).

78 There is an assumption that in rye evolution, from the time when Secale diverged from the

79 common ancestor with wheat, there was an increase in the DNA content, which was associated

80 with the addition of heterochromatin. It resulted in the formation of multiple copies of the same

81 DNA fragments (Bennett \& Smith, 1976). Comparisons of repetitive DNA sequences suggested

82 that rye, barley, wheat and oat had a common ancestor, and therefore, at the beginning of the 70s

83 of the twentieth century scientists began to determine the phylogenetic relationship and

84 interspecies similarity in the genus Secale (Flavell, Rimpau \& Smith,1977). Despite years of

85 research on the genus Secale, they have not been fully determined. The reason for this may be

86 that it is believed that in rye many evolutionary pathways exist (Tarkowski, 1983). Hence, there 
87 is a need to search for different methods to verify the proposed systems of classification and

88 phylogenetic relationships. It is now believed that studying the pattern of DNA methylation is

89 very important in explaining genome (Kalisz \& Purugganan, 2004). As mentioned above, the

90 evolution of the genus Secale proceeded with increasing amounts of heterochromatin, mainly

91 telomeric heterochromatin. This is clearly correlated with the size of their genomes. Secale

92 sylvestre has the lowest amount of t-heterochromatin (Sing \& Röbbelen, 1975), and has the

93 smallest genome (7.23 pg) (Bennett \& Smith, 1976) among the species of rye. Secale cereale is

94 considered evolutionarily the youngest species, having the most theterochromatin (Sing \&

95 Röbbelen, 1975) and the largest genome (8.28 pg) (Bennett \& Smith, 1976) among Secale. It is

96 then interesting whether the results of DNA methylation will confirm this relationship. Or

97 perhaps they will demonstrate the complexity of the process of DNA methylation and indicate

98 that the evolution of rye is not solely based on heterochromatin formation, but is associated with

99 a different methylation, which results in significant phenotypic differences between species.

100 The MSAP (Methylation-Sensitive Amplification Polymorphism) method was used to

101 compare the methylation status of the DNA fragments on a genomic scale between rye taxa. This

102 technique is based on the use of methylation-sensitive enzymes and the selective amplification of

103 restriction fragments obtained. MSAP combines the advantages of AFLP, which allows to

104 visualize multiple markers per sample, and to analyze cytosine methylation at the restriction site

105 (Baurens et al., 2003). MSAP is one of the latest methods, which has already been used in studies

106 of genome differentiation in cotton, banana, barley, Arabidopsis, tobacco and wild emmer wheat

107 (Baurens et al., 2003; Li et al., 2009; Yang et al., 2011). ELISA was another method used to

108 determine the level of global methylation in rye.

109 We analyzed the data concerning global (ELISA) and genomic scale cytosine methylation

110 (MSAP) in eight taxa of the genus Secale, together with information on the size of their genome

111 and the amount of t-heterochromatin. The aim of the research was to answer the question whether 
112 the cytosine methylation variation was consistent with phylogenetic relationships in the genus

113 Secale and whether it was evolutionarily related to the size of the genome and the amount of

114 telomeric heterochromatin.

115 MATERIALS AND METHODS

116 Plant material. - The following taxa of Secale were included in the study: Secale cereale L. cv.

117 Dankowskie Zielonkawe, Secale cereale ssp. afghanicum, Secale cereale ssp. segetale, Secale

118 strictum, Secale strictum ssp. africanum, Secale strictum ssp. kuprijanovii, Secale sylvestre and

119 Secale vavilovii.

120 Caryopses of all taxa mentioned above were obtained from Botanical Garden of Polish Academy

121 of Science (Warsaw, Poland).

122 DNA isolation. - Total genomic DNA was isolated from 7-day-old seedlings using the DNeasy

123 Plant Mini Kit (Qiagen, Valencia, USA) according to the manufacturer's instruction. Each DNA

124 extract was prepared from 30 randomly selected seedlings. The quality and quantity of the DNA

125 samples was assessed by $0.8 \%$ agarose electrophoresis in $1 \times \mathrm{TBE}$ buffer and measurements done

126 using Nanodrop 2000c spectrophotometer (Thermo Scientific, Vilnius, Lithuania).

127 MSAP. - $500 \mathrm{ng}$ of genomic DNA was digested with $1 \mu 1$ of FastDigest ${ }^{\circledR}$ EcoRI (Fermentas,

128 Vilnius, Lithuania) in a total volume of $50 \mu 1$ for $20 \mathrm{~min}$ at $37^{\circ} \mathrm{C}$. After EcoRI inactivation for 5

$129 \min$ at $80^{\circ} \mathrm{C}$ each sample was divided into two separate series: one for HpaII, one for. The DNA

130 samples were digested with $1 \mu \mathrm{l}$ of FastDigest ${ }^{\circledR}$ HpaII (Fermentas) and $1 \mu$ l of FastDigest $\AA$

$131 \mathrm{MspI}$ (Fermentas) in a total volume of $50 \mu \mathrm{l}$ for $30 \mathrm{~min}$ at $37^{\circ} \mathrm{C}$. Enzymes were inactivated by

132 incubation for $15 \mathrm{~min}$ at $65^{\circ} \mathrm{C}$. EcoRI and HpaII/MspI adapters (Table 1) were prepared by

133 mixing $50 \mu \mathrm{M}$ oligonucleotides in equal volumes and incubation at the following profile: $10 \mathrm{~min}$

134 at $65{ }^{\circ} \mathrm{C}, 10 \mathrm{~min}$ at $37^{\circ} \mathrm{C}, 10 \mathrm{~min}$ at $25^{\circ} \mathrm{C}, 10 \mathrm{~min}$ at $4{ }^{\circ} \mathrm{C}$. The restricted DNA was added the

135 ligation mixture $\left[2 \mu \mathrm{M}\right.$ Eco and Hpa/Msp adapter, $1 \times$ ligase buffer, $0.2 \mathrm{mM}$ dATP, $5 \mathrm{U} \mathrm{T}_{4}$ DNA

136 ligase (Fermentas)] and incubated for $3 \mathrm{~h}$ at $37^{\circ} \mathrm{C}$. The samples were diluted ten times, and $5 \mu \mathrm{l}$ 
137 of the diluted DNA was added to the preamplification mixture. The total volume of $50 \mu 1$ of 138 preamplification mixture also contained: $10 \mu \mathrm{M} \mathrm{Hpa}+\mathrm{A} / \mathrm{C}$ primer (Table 1), $10 \mu \mathrm{M}$ Eco $+\mathrm{A}$ 139 primer (Table 1), $1 \times$ polymerase buffer, $0.2 \mathrm{mM} \mathrm{dNTP}, 2.5 \mathrm{mM} \mathrm{MgCl} 2,2 \mathrm{U}$ DNA Polymerase 140 (DyNAzyme $^{\mathrm{TM}}$, Finnzymes, Espoo, Finland). The PCR conditions were as follows: initial 141 denaturation of $1 \mathrm{~min}$ at $94{ }^{\circ} \mathrm{C} ; 25$ cycles $-30 \mathrm{~s}$ at $94{ }^{\circ} \mathrm{C}, 60 \mathrm{~s}$ at $60{ }^{\circ} \mathrm{C}, 60 \mathrm{~s}$ at $72{ }^{\circ} \mathrm{C}$; final 142 elongation of $5 \mathrm{~min}$ at $72{ }^{\circ} \mathrm{C}$. The PCR products were diluted 20 times and $5 \mu \mathrm{l}$ of the diluted 143 sample was added to $15 \mu 1$ of selective amplification mixture. The final concentrations of the 144 components in the mixture were: $4 \mu \mathrm{M}$ Hpa selective primer (Table 1), $4 \mu \mathrm{M}$ Eco selective 145 primer (Table 1), 1 x polymerase buffer, $0.2 \mathrm{mM} \mathrm{dNTP,} 2.5 \mathrm{mM} \mathrm{MgCl} 2,0.5 \mathrm{U}$ DNA Polymerase 146 (DyNAzyme $^{\mathrm{TM}}$, Finnzymes). The PCR conditions were as follows: initial denaturation of $1 \mathrm{~min}$ at $94{ }^{\circ} \mathrm{C} ; 12$ cycles $-30 \mathrm{~s}$ at $94{ }^{\circ} \mathrm{C}, 30 \mathrm{~s}$ at $60{ }^{\circ} \mathrm{C}, 60 \mathrm{~s}$ at $72{ }^{\circ} \mathrm{C} ; 22$ cycles $-30 \mathrm{~s}$ at $94{ }^{\circ} \mathrm{C}, 30 \mathrm{~s}$ at 56 $148{ }^{\circ} \mathrm{C}$, $60 \mathrm{~s}$ at $72{ }^{\circ} \mathrm{C}$ final elongation of $30 \mathrm{~min}$ at $72{ }^{\circ} \mathrm{C}$. In total 35 different combinations of 149 selective primers were tested, out of which 9 combinations were chosen for the final analysis 150 (Table 1).

151 PCR products were separated on a $6.5 \%$ denaturing polyacrylamide gel. $100 \mathrm{ml}$ of the gel was 152 prepared from RapidGel ${ }^{\mathrm{TM}}-\mathrm{XL}-6$ \% Liquid Acrylamide (Affymetrix, Cleveland, USA) containing $1536 \%$ modified acrylamides, $7 \mathrm{M}$ Urea, $89 \mathrm{mM}$ Tris, $89 \mathrm{mM}$ boric acid and $2 \mathrm{mM}$ EDTA, and to 154 this solution $1000 \mu \mathrm{l}$ of $10 \%$ APS and $100 \mu 1$ of TEMED was added. Electrophoresis in $1 \times \mathrm{TBE}$ 155 buffer was carried out on the Sequi-Gen GT Sequencing Cell (Bio-Rad, Hercules, USA) with the 156 Power Pac ${ }^{\mathrm{TM}}(\mathrm{Bio}-\mathrm{Rad})$ as a power supply unit. The gel was pre-electrophoresed for $1 \mathrm{~h}(100 \mathrm{~W}$, $1572000 \mathrm{~V}, 50 \mathrm{~mA}$ ). Loading buffer (98\% formamide, $20 \mathrm{mM}$ EDTA, 0,01\% bromophenol blue, $1580,01 \%$ xylene cyanol) was added to the samples $(12 \mu 1$ per $20 \mu 1)$, the mixture was denatured at $95^{\circ} \mathrm{C}$ for $5 \mathrm{~min}$, placed in ice for $10 \mathrm{~min} .7 \mu \mathrm{l}$ of the mixture from each samples were loaded in 160 the wells. Simultaneously with the samples the pBR322 DNA/BsuRI (HaeIII) marker 161 (Fermentas) was prepared and loaded onto gel. Electrophoresis was carried out for $2.5 \mathrm{~h}(100 \mathrm{~W}$, 
$1622000 \mathrm{~V}, 50 \mathrm{~mA}$ ). After electrophoresis bands were detected by silver staining technique using 163 Silver Sequence ${ }^{\mathrm{TM}}$ DNA Sequencing System (Promega, Madison, USA), according to 164 manufacturer's protocol. The documentation and analysis of the gels were done by means of GS165800 Calibrated Densitometer (Bio-Rad) and Quantity One ${ }^{\circledR}$ ver. 4.6 .9 (Bio-Rad) software.

166 MSAP procedure was repeated - three biological replicates were performed. Reproducible, 167 clearly distinguishable fragments were scored in a form of binary matrix as either present (1) or 168 absent (0) for the samples. MSAP markers were classified as different types: $11,01,10$, or 00 169 accordingly to the presence (1) or absence (0) of the corresponding amplified fragment in the 170 digestion reactions with $H p a \mathrm{II}$ and $M s p \mathrm{I}$, respectively.

171 Assessment of methylation level (\%) of Methylation-Susceptible Loci (MSL), Principal

172 Coordinate Analyses (PCoA) and Neighbor-Joining tree were done by means of R program (R 173 version 3.2.2) with msap package.

174 UPGMA (unweighted pair group method using arithmetic averages algorithm was used for 175 cluster analysis in order to show the relationships between taxa. Dice Index was computed in 176 FreeTree (Pavlicek, Hrdá \& Flegr, 1999) program and the dendrogram was visualized in 177 TreeView (Page, 1996) program. Bootstrapping with 1000 repetition was done in Free Tree 178 program. The data from double matrix including: 11, 01, 10 and 00 types were transformed into 179 single 1/0 matrix, in which 1 represented any type of methylated fragment (types: 01,10 or 00 ) 180 and 0 represented unmethylated fragment (type 11).

181 The analysis of differences between the taxa ( $U$-values) was based on the suggestion of Wang et 182 al. (2014):

$183 \mathrm{p}=\frac{y 1+y 2}{n 1+n 2}$

$184 \mathrm{q}=1-\mathrm{p}$ 
$\delta_{p 1-p 2}=\sqrt{ }(p q(1 / n 1)+1 / n 2)$

$186 \mathrm{U}=\frac{p 1-p 2}{\delta_{p 1-p 2}}$

where $\mathrm{n} 1$ represents the total number of fragments of a given sample, $\mathrm{n} 2$ the total fragments of another sample, y1 the total number of methylated fragments of a given sample values, y2 the total number of methylated fragments in another sample, p1 the proportion $(\%)$ of methylated fragments of a given sample values and $\mathrm{p} 2$ the proportion $(\%)$ of methylated fragments in another

191 sample.

Giemsa staining. - Roots from 2 -day-old seedlings were treated with $0.05 \%$ colchicine for $3 \mathrm{~h}$ at room temperature in the dark prior to fixation in ethanol-glacial acetic acid $(3: 1)$. Roots were macerated in a mixture of $4 \%(\mathrm{w} / \mathrm{v})$ pectinase (Fluka), $6 \%(\mathrm{w} / \mathrm{v})$ hemicellulase (Sigma-Aldrich, St. Louis, USA) and $4 \%(\mathrm{w} / \mathrm{v})$ cellulase (Sigma-Aldrich) in $0.01 \mathrm{M}$ citric acid - sodium citrate buffer ( $\mathrm{pH} 4.8$ ), for $3 \mathrm{~h}$ at $37^{\circ} \mathrm{C}$. Roots were washed in distilled water. Each root tip were dissected on a single microscope slide, a drop of $45 \%$ acetic acid was added and the root tip was squashed under a cover glass. Preparations were heated for $20 \mathrm{~min}$ at $47^{\circ} \mathrm{C}$. The cover slip was removed after freezing over dry ice, and the slides were air-dried overnight. Chromosomes were stained with Giemsa reagent according to Darvey and Gustafson (1975) and Merker (1976). Preparations were analyzed under Eclipse E600 microscope (Nikon, Tokyo, Japan). NIS Elements ver. 3.00 SP7 (Nikon) software was used to measure: total chromosomes lengths, arms lengths and telomeric $\mathrm{C}$-bands lengths. Based on the measurements the percentage of total telomeric heterochromatin content in the genome of each Secale taxon was computed. The Kruskal-Wallis test was performed in Statistica software ver. 12.

ELISA. - The 5-mc DNA ELISA Kit (Zymo Research, Irvine, USA) was used to detect global 5methylocytosine in the DNA. $100 \mathrm{ng}$ of each sample DNA was used in the assay. Four replicates 
208 of each sample were prepared in a single experiment, and the experiment was repeated three

209 times. The analysis was performed according to the manufacturer's instruction. Adequate controls

210 included in the were used in the experiments. Plates were read in the Infinite ${ }^{\circledR}$ M200 Pro

211 microplate reader (Tecan, Crailsheim, Germany). Magellan ${ }^{\mathrm{TM}}$ ver. 7.0 (Tecan) software was used

212 to generate the standard curve and to quantify the percentage of 5-mC in DNA samples. The

213 Tuckey test was performed in Statistica software ver. 12.

214 Flow cytometry. - $20 \mathrm{mg}$ of coleoptiles from 7-day-old seedlings were chopped in $1 \mathrm{ml}$ of ice215 cold nuclei isolation buffer (45 mM MgCl $2 \cdot 6 \mathrm{H}_{2} \mathrm{O}, 20 \mathrm{mM} \mathrm{MOPS,} \mathrm{0,1 \%} \mathrm{(v/v)} \mathrm{Triton} \mathrm{X-100,} 1 \%$

216 PVP; pH 7.0) supplemented with propidium iodide (Sigma-Aldrich; $50 \mu \mathrm{g} / \mathrm{mL}$ ) and ribonuclease 217 A (Sigma-Aldrich; $50 \mu \mathrm{g} / \mathrm{mL}$ ). The homogenate was filtered through a 42-mm nylon mesh into a $2181.5 \mathrm{ml}$ tube and incubated for $10 \mathrm{~min}$ at ice. Secale cereale was used as an internal standard. The 219 measurements were done at the rate $20-50$ nuclei. For each sample, fluorescence in at least 7000 220 was measured using BD FACSCalibur ${ }^{\mathrm{TM}}$ flow cytometer (Becton Dickinson, San Jose, USA). The 221 mass of the genome was calculated from the formula below:

$$
\text { Sample } 2 C \text { value }(p g)=\text { Reference } 2 C \text { value } \times \frac{\text { Sample } 2 C \text { mean peak position }}{\text { Reference } 2 \text { C mean peak position }}
$$

222 Reference 2C value for Secale cereale $=16.55 \mathrm{pg}$ (Bennett \& Smith, 1976).

223 Histograms were analyzed using the CellQuest ${ }^{\mathrm{TM}}$ Pro (Becton Dickinson) software. The results 224 were estimated using Tuckey test (Statistica software ver. 12).

\section{RESULTS}

MSAP. - Methylation profiling by MSAP relies on the use of methylation-sensitive enzymes. In this work we used a pair of enzymes, MspI and HpaII, which recognize the 5'-CCGG-3' 
230 the DNA when the cytosine is fully methylated, and it cuts the DNA when the external cytosine is

231 hemimethylated (Table 2). Therefore, the application of this pair of enzymes in MSAP allows to 232 specify 4 different methylation states of the 5'-CCGG-3' sequence: type 11 - no methylation, type 23301 - methylated $\mathrm{CpG}$ sequence, type 10 - hemimethylated sequence or methylated $\mathrm{CpCpG}$ 234 sequence, type 00 - hypermethylation (Table 2). In type 4, it is also possible that no band in a 235 given taxon does not result from changes in the methylation state, the reason may be the lack of 236 this sequence. Hence, the MSAP analysis may introduce some error. However, based on the 237 conducted experiments, including less clear bands omitted in this analysis, it could be said that 238 band patterns of the examined rye taxa were very similar to each other, and even if the analysis 239 was burden with the above-described error, it was small. Before we performed the MSAP 240 analysis, some preliminary tests with the classical AFLP technique had been done (data not 241 published). We calculated the Dice coefficient for each pair of species/subspecies. The values 242 were high $(0.89-0.95)$, thus we decided that MSAP analysis would be reliable. The values of the 243 coefficient were not surprising as from ISSR and IRAP analyses, which allow to study the 244 polymorphism of highly variable inter-microsatellite and inter-retrotransposon sequences, the 245 values were not low, $0.48-0.85$ (IRAP) and $0.39-0.82$ (ISSR) (Achrem et al., 2014). We were 246 also aware that MSAP can analyze a small quantity of methylated cytosines in the genome that is 247 why we also complemented with global methylation data, which shed more light on the variation 248 of methylation in Secale.

249 To ensure the robustness of the results, the analysis included only the most evident and repetitive 250 fragments in the size range 50-500 nt. In total, 149 loci were selected of all the reactions 251 performed with 9 primer combinations. Among these loci, 98 methylation-susceptible loci (MSL) 252 and 51 non-methylated loci (NML) were distinguished. The number of polymorphic MSL was 14 253 (14\% of total MSL) and the NML was 7 (14\% of total NML). The level of methylation of MSL 254 loci is shown in Fig. 1, which demonstrates that type 01 (internal methylated cytosine) and type 
25500 (hypermethylation) fragments are most frequent among rye taxa, reaching approximately $43 \%$ 256 and 38\%, respectively. Type 11 fragments were definitely the least frequent (approx. 7\%), and 257 were followed by slightly more frequent type 10 - (approx. 12\%).

258 Both the MSL analysis alone (Fig. 2) and the combined analysis of MSL and NML loci (Fig. 3) 259 showed that $S$. sylvestre was the most distinct from other species. Secale vavilovii also showed 260 greater epigenetic variation in relation to the taxa belonging to the species $S$. cereale and $S$. 261 strictum. The total methylation level of the studied loci was very similar in all taxa (Fig. 4). The $262 U$ values were calculated between all taxa to verify whether the differences in the level of 263 methylation are statistically significant. Higher U values indicated greater differences between 264 taxa, but only $U$ values $>1.96\left[U_{(0.05)}=1.96\right]$ would mean statistically significant differences. The $265 \mathrm{U}$ values in the studied rye taxa ranged between 0 for $S$. sylvestre and $S$. vavilovii, S. sylvestre and 266 S. cereale, $S$. cereale and $S$. vavilovii and 1.25 for Secale s. ssp. africanum and $S$. c. ssp. segetale, 267 indicating that the methylation pattern did not differ significantly between any pair of taxa (Table 268 3). Dice coefficients confirmed this high similarity (Table 3), as it ranged between pairs of 269 individual taxa from $87 \%$ (S. sylvestre and $S$. s. ssp. kuprijanovii) to $96 \%$ (S. cereale and $S$. s. ssp. 270 kuprijanovii, $S$. cereale and $S$. c. ssp. segetale, $S$. c. ssp. segetale and $S$. s. ssp. kuprijanovii). 271 Since the rye taxa investigated in this study belonged to 4 species, it was very interesting how 272 epigenetically similar to each other were subspecies within the species. Such analysis was 273 conducted and the graphical representation is shown in Fig. 2. Fig. 2a shows the variation 274 between the taxa without grouping them in species, while Fig. 2b shows the variation between 275 species. Dendrogram (Fig. 2c) shows the relationship between 8 rye taxa grouped into 4 species. 276 The results clearly indicated that epigenetic similarity between species was sufficiently

277 significant so that the subspecies of $S$. cereale and $S$. strictum did not group together. The 278 bootstrapping analysis confirmed this result (Fig. 3). Low values obtained indicated that the 
279 presented clustering of taxa was unreliable, and only $S$. sylvestre was definitely different from

280 other taxa, but these differences were not statistically significant.

281 Giemsa staining. - Thirty preparations of root tips of each rye taxa were prepared in order to

282 determine the total percentage of telomeric heterochromatin. Five preparations were analyzed in

283 detail, in which 9 best metaphase plates were selected and the following measurements were

284 performed in them: the overall length of each chromosome, short and long arm length, the length

285 t-heterochromatin bands in individual chromosomes. On this basis, the total percentage of

286 telomeric heterochromatin was calculated in the whole genome of each taxon. The results showed

287 that the content of t-heterochromatin was varied (Fig. 4): the lowest amount of t-heterochromatin

288 was found in S. sylvestre (6.18\%) (Fig. 6B), S. s. ssp. africanum (6.25\%), S. strictum (7.18\%) and

289 S. s. ssp. kuprijanovii (7.72\%). No significant differences in the content of t-heterochromatin

290 were found between these taxa (Table 4). More t-heterochromatin was present in the genomes of

291 S. c. ssp. segetale (10.94\%), S. c. ssp. afghanicum (11.90\%), S. cereale (12.29\%) and S. vavilovii

$292(13.39 \%)$ (Fig. 6A). In this case, also no significant differences were recorded between these

293 taxa. Therefore, these Secale taxa could be divided into two groups, with a relatively lower and

294 higher content of t-heterochromatin. In contrast to the MSAP method, the results of which

295 showed that there are no significant differences between all taxa, and the taxa of the species $S$.

296 cereale and $S$. strictum did not cluster together, the analysis of the content of t-heterochromatin

297 confirmed the currently accepted taxonomic relationships. Admittedly, species that were the most

298 different from others in the MSAP analysis, here also had the lowest (S. sylvestre; 6.18\%) and the

299 highest (S. vavilovii; 13.39\%) t-heterochromatin contents. While the remaining taxa in the group

300 with smaller amounts of heterochromatin-t belonged to the species S. strictum, and in the group

301 with a higher t-heterochromatin content they belonged to the species $S$. cereale. Nevertheless,

302 there were no statistically significant differences found in the t-heterochromatin content between

303 S. s. ssp. kuprijanovii and S. c. ssp. segetale and S. c. ssp. afghanicum. 
304 ELISA. - In total, 12 measurements of the global cytosine content were performed in the genome 305 of each of the rye taxa. Five taxa had a similar level of methylated cytosine (Fig. 4) and no 306 significant differences were observed (Table 4) between S. c. ssp. afghanicum (74.41\%), S. s. ssp. 307 africanum (69.52\%), S. cereale (69.80\%), S. s. ssp. kuprijanovii $(67.05 \%)$ and S. vavilovii 308 (66.42\%). Slightly lower level of methylation was detected in S. sylvestre (61.09\%) and it only 309 differed from the methylation state of S. c. ssp. afghanicum of the above-listed taxa. Very high 310 content of 5-methylcytosine $(82.86 \%)$ was found in $S$. c. ssp. segetale. In this case, it has a 311 significantly higher level of methylation compared to the genomes of all the other taxa, with the 312 exception of $S$. c. ssp. afghanicum. On the other hand, extremely low levels of DNA methylation 313 was present in S. strictum (52.56\%) and differed significantly from the methylation status of all 314 taxa besides $S$. sylvestre.

315 The level of global cytosine methylation in DNA, as opposed to the total t-heterochromatin in the 316 genome, did not overlap with the current taxonomic relationships. Within three taxa belonging to 317 the species $S$. cereale: S. cereale, S. c. ssp. afghanicum and S. cereale differed significantly from 318 S. c. ssp. segetale, while in the taxa belongong to S. strictum: subspecies $S$. strictum subsp. 319 strictum were different from the other two subspecies $S$. s. ssp. africanum and $S$. s. ssp. 320 kuprijanovii.

321 It is not surprising that the results of methylation analysis of the CCGG sequence by MSAP did 322 not overlap with global analysis of cytosine methylation by ELISA, as in plant genomes, in 323 addition to the methylation of $\mathrm{CG}$ sequences, $\mathrm{CNG}$ and $\mathrm{CNN}$ sequence methylation also occurs 324 (Johnson et al., 2007; Meyer, 2011; González et al., 2013). Thus, it was possible that the CpG 325 methylation was similar in the genomes of all Secale taxa tested, while such high differences in 326 the level of 5-methylcytosine were due to differences in the $\mathrm{CNG}$ and $\mathrm{CNN}$ methylation. In 327 addition, the MSAP method allowed to examine only selected loci in a limited number, which 328 might not give a complete picture of epigenetic variation. 
329 Flow cytometry. - The DNA content in the nucleus of the studied Secale taxa was the lowest in

330 S. s. ssp. africanum (14.76 pg) and S. s. ssp. kuprijanovii (15.23 pg), in which it did not exceed $33116 \mathrm{pg}$. All other taxa had the $2 \mathrm{C}$ value above $16 \mathrm{pg}$, with the largest amount of DNA measured in 332 S. vavilovii (Fig. 5). It was this rye species that differed significantly from S. s. ssp. africanum (P $333<0.001)$ and $S$. s. ssp. kuprijanovii $(\mathrm{P}=0.007)$. In other cases, there were no significant 334 differences in the DNA content in the nucleus $(\mathrm{P}>0.05)$.

DISCUSSION

DNA methylation is involved in many important processes in plants, including the regulation of gene expression, gene imprinting or growth and differentiation of plants (Finnegan et al., 1998). This is a dynamic process, differences in which depend on the degree of development or tissue type. The MSAP technique was used in the study to determine the polymorphism methylation level between species of the genus Secale. Methylation of the CCGG sequence was evaluated by using the combination of MspI and HpaII restriction enzymes. The level of methylation in the test species was high and ranged from 60 to $66 \%$. Very similar methylation level was determined by MSAP in Triticum turgidum ssp. dicoccoides (Venetsky et al., 2015). However, using the same method, Shaked et al. (2001) found that the level of cytosine methylation in T. turgidum ssp. durum reached only 35\%. The results showed a higher degree of DNA methylation in Secale taxa compared with the species of the genus Cycas (Sea-Eung, 2011) or species such as Brassica oleracea (Salmon et al., 2008), Elaeis guineensis (Jaligot et al., 2004) or Arabidopsis thaliana (Cervera, Ruiz-García \& Martínez-Zapater, 2002), which may be caused by a higher number of repeated sequences (up to $92 \%$ ) in the genomes of species of the genus Secale (Flavell, Rimpau \& Smith,1977). 
353 which was consistent with previous studies on the phylogeny of rye (Reddy, 1990; Del Pozo,

354 1995; De Bustos \& Jouve, 2002; Chikmawati, Skovmand \& Gustafson, 2005; Shang, 2006;

355 Achrem, Kalinka \& Rogalska, 2014). The dissimilarity of this species in relation to other Secale

356 taxa was confirmed by molecular analysis of plastid DNA (Murai, Naiyu \& Tsunewaki, 1989;

357 Petersen \& Doebly, 1993), repetitive sequences (Cuadrado \& Jouve, 2002; Shang et al., 2006;

358 Zhou et al., 2010; Achrem, Kalinka \& Rogalska, 2014), 18S - 5.8S - 26S rDNA (De Bustos \&

359 Jouve, 2002) or AFLP (Chikmawati, Skovmand \& Gustafson,2005). The cited studies confirm the

360 hypothesis of Singh and Röbbelen (1975) and Bennett, Gustafson \& Smith (1977), that $S$.

361 sylvestre is most likely phylogenetically the oldest among Secale species. Cuadrado and Jouve

362 (2002), when examining the distribution of SSR sequences in the chromosomes of different taxa

363 of rye, found that $S$. sylvestre separated earlier from the other species of the genus Secale. The

364 lack of $480 \mathrm{bp}$ family sequences in this species, indicated that this sequence could be amplified in

365 the evolution of the genus Secale after the divergence of this taxon from a common ancestor. It

366 can be concluded that the amplifications and deletions of repetitive sequences in the genomes of

367 rye formed a basis of the evolutionary pathway of this genus (Cuadrado \& Jouve, 2002), which

368 also affected the level of DNA methylation. However, the differences between S. sylvestre and

369 other rye taxa, demonstrated by the MSAP technique, were not statistically significant. It seems

370 that genus Secale is not an exception. Epigenetic distance calculated on the basis of MSAP

371 among three diploid Limonium species (L. nydeggeri, L. ovalifolium, L. lanceolatum) was very

372 low. It ranged from 0.002 to 0.029 between pairs of individual species (Róis et al., 2013).

373 The higher epigenetic diversity of $S$. vavilovii compared to other rye taxa was surprising, 374 however, as in the case of $S$. sylvestre, it was not statistically significant. The results confirmed

375 that this species was very similar to $S$. cereale (Table 3), and confirmed the assumption that they

376 might share a common ancestor. This thesis was also consistent with the study of Ren et al.

377 (2011) and Bobolik-Bragoszewska et al. (2015), where this species was even classified as a 
378 subspecies of $S$. cereale. Osabe et al. (2014) observed different methylation levels at a low

379 genetic variation in the genotypes of cotton, which were grown under the same environmental 380 conditions over many generations. Similar results in other crops suggest the involvement of 381 methylation changes, compensating for the absence of genetic variation (Fang et al., 2008; Fang 382 et al., 2010).

383 The use of the MSAP method alone does not provide a complete methylation picture. This 384 technique is limited by recognizing methylation only at the CCGG sites and not entirely reliable 385 detection of hypermetylated regions. In plants, DNA methylation is not restricted to CpG islands 386 only, as it occurs in three sequence contexts - $\mathrm{CG}, \mathrm{CHG}$ and $\mathrm{CHH}(\mathrm{H}=\mathrm{A}, \mathrm{C}$ or $\mathrm{T})$ (Bender, 387 2004; Salmon et al., 2008; Kim et al., 2015), which are characterized by a specific pattern of 388 inheritance and have their own regulatory pathways. However, numerous literature data suggest 389 that the highest level of methylation is usually obtained in the CG context, intermediate in the 390 CHG context, and the lowest level of methylation is observed in CHH (Feng et al., 2010; Eichten 391 et al., 2016; Osabe et al. 2014; Salmon et al., 2008). On this basis, MSAP results can be 392 considered to be meaningful when comparing epigenomes.

393 Another issue that should be raised here is that MSAP patterns might be in certain circumstances 394 ambiguous (Fulneček \& Kovařík, 2014). According to Fulneček et al. (2002) or Cokus et al. 395 (2008) the most frequent status of CCGG methylation is $\mathrm{C}^{\mathrm{m}} \mathrm{CGG}$, less frequent ${ }^{\mathrm{m}} \mathrm{C}^{\mathrm{m}} \mathrm{CGG}$ while $396{ }^{\mathrm{m}} \mathrm{CCGG}$ is the rarest. It is consistent with our results. However, as a consequence, in the regions 397 where CCGG motifs are closely located, in of some HpaII-EcoRI fragments internal $\mathrm{C}^{\mathrm{m}} \mathrm{CGG}$ 398 might be located. The digestion of HpaII-EcoRI by MspI would cause to the misinterpretation of 399 the MSAP pattern (Fulneček \& Kovařík, 2014). Thus, as the interpretation of type 11 and type 01 400 patterns is not complicated, the patterns of 10 fragments may be more ambiguous. Considering 401 this, we might expect, that the calculated methylation level based on MSAP, may not perfectly 402 correspond to the actual methylation level of analyzed fragments. On the other hand, it did not 
403 affected the assessment of the Secale taxa similarity because the MSAP patterns were strikingly 404 similar.

405 The ELISA technique was applied to complement MSAP results and elucidate global methylation 406 in the species of the genus Secale. Determination of global methylation level of all cytosines in 407 the DNA has its own drawbacks, as it does not provide information about the genomic position of 408 methylated cytosines. However, knowledge of the global methylation may reflect functional 409 changes in the genome, such as mutations, genomic stability, gene expression changes or 410 chromosomal rearrangements (McClintock, 1984; Steward et al., 2002; Feschotte \& Pritam, 411 2007; Rozhon et al., 2008; Bonchev \& Parisod, 2013; Alonso et al., 2015). The level of global 412 methylation turned out to be very high and ranged from $53 \%$ in $S$. strictum to $83 \%$ in $S$. c. ssp. 413 segetale. In most species, as expected, it was higher than that obtained using MSAP, with the 414 exception of species, such as $S$. strictum and $S$. sylvestre. It is possible that the CpG methylation 415 was similar in the genomes of all Secale taxa tested, while such high differences in the level of 5416 methylcytosine were due to differences in the CNG and CNN methylation. In addition, the MSAP 417 method allows to examine only selected loci in a limited number, which may not give a complete 418 picture of epigenetic variation. The obtained variability in DNA methylation patterns among the 419 tested taxa of rye was at a rather low level. However, it showed that in the process of evolution, 420 each taxon accumulated epialleles and faithfully passed them on from generation to generation, 421 which resulted in differences in the obtained percentages and changes in DNA methylation 422 patterns between the taxa.

423 DNA methylation is an epigenetic mechanism that is directly related to the 424 heterochromatin fraction in the genome. Thus the evolutionary increase of genome sizes by 425 heterochromatin addition affects the complexity of the genome and must be associated with 426 increasing levels of global cytosine methylation in DNA (Fedoroff, 2012). This was confirmed by 427 the study of Alonso et al. (2015) concerning the correlation between global methylation and the 
428 size of the genomes of 54 angiosperm species. The evolution of the species Secale proceeded

429 with the addition of heterochromatin, especially telomeric heterochromatin, and consequently an 430 increase in genome size. Therefore, in this study, the results of DNA methylation were 431 complemented with the data on genome size and the amount of theterochromatin of individual 432 taxa. This hypotheses were confirmed by the results of MSAP, and ELISA analyses, obtained in 433 the taxon $S$. c. ssp. segetale. It was characterized by the highest methylation percentage, which 434 positively correlated with a high DNA content - $16.07 \mathrm{pg}(2 \mathrm{C})$, and large blocks of telomeric 435 heterochromatin, which constituted as much as $11 \%$. This relationship was similar in $S$. c. ssp. 436 afghanicum and $S$. cereale. Hence it would seem that with increasing genome size, the level of 437 DNA methylation will also increase. However, the results obtained in this study are evidence that 438 the percentage of methylated cytosine can not be inferred solely based on the genome size or t439 heterochromatin. This is a significantly more complex issue. Alonso et al. (2015) demonstrated 440 that methylation level increased slower than genome size. These authors concluded that during 441 evolution when an increase in DNA content occurred, the content of methylated cytosine steadily 442 decreased (Alonso et al., 2015). This may be due to the reduced percentage of repetitive 443 sequences in the genome as compared with its size or due to methylation density of repetitive 444 sequences. This study demonstrated that $S$. $s$. ssp. africanum had the smallest genome (2C $44514.76 \mathrm{pg}$ ), and it also had the lowest percentage of telomeric heterochromatin (6\%). However, in 446 contrast to the expected value, the global methylation was high and reached $70 \%$. This can be 447 explained by the fact that it is an endemic species, which occurs only in South Africa and its 448 evolution could be different compared to other rye taxa or subspecies S. strictum (Hammer, 449 1990). However, this example confirms that the increasing genome size in Secale does not 450 necessarily means higher level of DNA methylation. Lower than the expected value of the global 451 methylation was detected in $S$. vavilovii $(66 \%)$ at high DNA $(2 \mathrm{C}-16.66 \mathrm{pg})$ and t452 heterochromatin contents $(13 \%)$. This variation in the level of DNA methylation may be due to 
453 changes resulting from the adaptive process of plants, wherein the methylation is an important

454 epigenetic mechanism (Sea-Eung, 2011. The process of DNA methylation/demethylation may

455 affect the inhibition or activation of a gene or the entire range of different genes in different

456 environment in order to adapt the species to changing biotic and abiotic conditions. Many

457 literature data showed that changes in the level of genome methylation occurred even after short-

458 term exposure of plants to pathogens, low temperature or drought (Steward et al., 2002; Lukens

459 \& Zhan, 2007; Peng \& Zhang, 2009; Verhoeven et al., 2010; Grativol, Hemerly \& Ferreira, 2012;

460 Alonso et al., 2014). Therefore, differences in DNA methylation may be caused by the adaptation

461 of organisms to a particular environment (Finnegan, 2001). This was the conclusion drawn from

462 MSAP and TMD (transposon methylation display) analyses of natural population of emmer

463 wheat (T. turgidum ssp. dicoccoides), in which the level of DNA methylation was modified by the

464 influence of the environmental factors (Venetsky et al., 2015). This also may be the reason of

465 such a low level of global DNA methylation in S. strictum (53\%), as compared to other taxa, and

466 even its subspecies, despite the high DNA content $(2 \mathrm{C}-16.22 \mathrm{pg})$. The lack of relationships

467 between the t-heterochromatin content and the level of global cytosine methylation in Secale may

468 be also explained by the fact, that not only DNA methylation but also other epigenetic

469 mechanisms are involved in maintaining the constitutive heterochromatin state (Soppe et al.,

470 2002). The evidence comes from the studies on barley, in which differences in chromosomal

471 distribution of constitutive heterochromatin and 5-mC pattern were found (Castiglione et al.

472 2008).

473 Additionally, genome size enlargement could occur in various species through the

474 accumulation of other types of sequences, which would be associated with their different

475 methylation levels. A large part of the genome size variation is caused by the differences in the

476 presence and amplification of transposable elements, especially retrotransposons (Bennetzen et

477 al., 1998; Pearce et al., 1996; Vincient et al., 2001; Schulman, Flavell \& Ellis, 2004; Grover \& 
478 Wendel, 2010). Mobile genetic elements are often the main target of DNA methylation in plants

479 (Hirochika, Okamoto \& Kakutani, 2000; Kato et al., 2003; Salmon et al., 2008, because they 480 should be silenced to ensure the stability and integrity of the genome. Thus changes in DNA 481 methylation can be related to the presence or absence of transposable elements in the genome. It 482 is associated with a different number of transposable elements, as well as the specificity of certain 483 transposable elements that could be subject to amplification in the genome of a particular species 484 after the evolutionary separation. It should be noted that epigenomic changes may occur under 485 stress, particularly changes in the level of DNA methylation and activation of transposable 486 elements. Especially in the case of retrotransposons it can be connected with a significant 487 increase in genome size (Kim \& Zilberman, 2014; Mirouze \& Vitte, 2014; Hollister et al., 2011; 488 Eichten et al., 2012; Eichten et al., 2013; Eichten et al., 2016). Although many examples show 489 variation resulting from the absence or presence of TEs, leading to changes in DNA methylation 490 (Gaut \& Hollister, 2009; Hollister et al., 2011; Eichten et al., 2012; Eichten et al., 2013; Eichten 491 et al., 2016; Ahmed et al., 2011), there are studies showing a minimal relationship between the 492 variation of transposable elements and methylation (Li et al., 2015). They may result for example 493 from the fact that insertions and deletions of TEs concern heterochromatin regions, leading to 494 minimal changes in overall DNA methylation patterns (Eichten et al., 2016).

495 It is believed that since the genetic activity of TEs in plant is strictly dependent on their 496 methylation, reducing their methylation with expanding genome size may increase the chances of 497 genetic, phenotypic or evolutionary effects of TE action in plants with larger genomes (Banks \& 498 Federoff, 1989; Bonchev \& Parisod, 2013; Alonso et al., 2015).

500 The genome enlargment and heterochromatinization can influence the global methylation level. However, 501 such dependency did not apply to each studied Secale taxon. Gathering of various types of sequences may 
502 result in the increase of the DNA quantity in the genome, but as not all of them are highly methylated, the 503 differences in the DNA methylation level are not surprising. Additionally, various events during the 504 evolution of Secale taxa could affect their epigenomes. The results obtained in this study are evidence 505 that the percentage of methylated cytosine cannot be inferred solely based on the genome size or 506 t-heterochromatin. This is a significantly more complex issue.

\section{ABBREVIATIONS}

508 MSAP, Methylation-Sensitive Amplification Polymorphism; ELISA, enzyme-linked 509 immunosorbent assay; MSL, methylation-susceptible loci; NML, non-methylated loci; PCoA, 510 Principal Coordinate Analyses; IRAP, inter-retrotransposon amplified polymorphism; TE, 511 transposable elements; MOPS, 3-(N-morpholino)propanesulfonic acid, TBE, Tris-borate-EDTA; 512 APS, ammonium persulfate; TEMED, 1,2-Bis(dimethylamino)ethane.

\section{ACKNOWLEDGEMENTS}

514 The authors are very grateful to prof. Jolanta Tarasiuk and Dr. Agnieszka Maruszewska for their 515 help in the flow cytometric analysis. They also wish to thank Dr. Anetta Wieczorek for her help in 516 the statistical analysis.

\section{REFERENCES}

518 1. Achrem M, Kalinka A, Rogalska S. 2014. Assessment of genetic relationships among Secale 519 taxa by using ISSR and IRAP markers and the chromosomal distribution of the AAC 520 microsatellite sequence. Turkish Journal of Botany 38:213-225. DOI:10.3906/bot-1207-26. 
521 2. Ahmed I, Sarazin A, Bowler C, Colot V, Quesneville H. 2011. Genome-wide evidence for 522 local DNA methylation spreading from small RNA-targeted sequences in Arabidopsis. Nucleic 523 Acids Research 39:6919-6931. DOI: 10.1093/nar/gkr324

524 3. Alonso C, Pérez R, Bazaga P, Herrera CM. 2015. Global DNA cytosine methylation as an 525 evolving trait: phylogenetic signal and correlated evolution with genome size in angiosperms. 526 Frontiers in Genetics 6, 4. DOI: 10.3389/fgene.2015.00004.

527 4. Alonso C, Pérez R, Bazaga P, Medrano M, Herrera CM. 2014. Individual variation in size and 528 fecundity is correlated with differences in global DNA cytosine methylation in the perennial 529 herb Helleborus foetidus (Ranunculaceae). American Journal Botanical 101:1309-1313. DOI: $530 \quad 10.3732 / a j b .1400126$.

531 5. Banks J, Fedoroff N. 1989. Patterns of developmental and heritable change in methylation of 532 the Suppressor-mutator transposable element. Developmental Genetics 10:425-437. 533 DOI: $10.1002 /$ dvg.1020100604.

534 6. Baurens P, Bonnot F, Bienvenu D, Causse S, Legavre T. 2003. Using SD-AFLP and MSAP to 535 assess CCGG methylation in the banana genome. Plant Molecular Biology 21:339-348. DOI: $536 \quad 10.1007 / \mathrm{BF} 02772583$.

537 7. Bender J. 2004. DNA methylation and epigenetics. Annual Review of Plant Biology. 55:41$538 \quad$ 68. DOI: 10.1146/annurev.arplant.55.031903.141641.

539 8. Bennett M, Leitch I. 2012. Angiosperm DNA C-values database. (release 8.0, Dec. 2012), in: $540 \quad$ http://www.kew.org/cvalues/.

541 9. Bennett MD, Smith JB. 1976. Nuclear DNA amounts in angiosperms. Philosophical 542 transactions of the Royal Society B 274:227-274. DOI: 10.1098/rstb.1976.0044.

543 10. Bennett MD, Gustafson JP, Smith JB. 1977. Variation in nuclear DNA in the genus Secale. 544 Chromosoma 61:149-176. DOI:10.1007/BF00327398 
545 11. Bennetzen J, Sanmiguel P, Chen M, Tikhonov A, Francki M, Avramova Z. 1998. Grass

546 genomes. Proceedings of the National Academy of Sciences of the United States of America $547 \quad 95: 1975-1978$.

548 12. Bird A. 1995. Gene number, noise reduction and biological complexity. Trends in Genetic 549 11:94-100. DOI: 10.1016/S0168-9525(00)89009-5.

550 13. Bird A, Wolffe AP. 1999. Methylation-induced repression-belts, braces, and chromatin. Cell $55199: 451-454$.

14. Bolibok-Bragoszewska H, Targońska M, Bolibok L, Kilian A, Rakoczy-Trojanowska M. 2015. Genome-wide characterization of genetic diversity and population structure in Secale. BMC Plant Biology 14:184. DOI: 10.1186/1471-2229-14-184.

15. Bonchev G, Parisod C. 2013. Transposable elements and microevolutionary changes in natural populations. Molecular Ecology Resources 13:765-775. DOI: 10.1111/17550998.12133.

16. Castiglione MR, Venora G, Ravalli C, Stoilov L, Gecheff K, Cremonini R. 2008. DNA methylation and chromosomal rearrangements in reconstructed karyotypes of Hordeum vulgare L. Protoplasma 232: 215. DOI:10.1007/s00709-007-0275-6.

17. Cervera MT, Ruiz-García L, Martínez-Zapater JM. 2002. Analysis of DNA methylation in Arabidopsis thaliana based on methylation-sensitive AFLP markers. Molecular Genetics and Genomics 268: 543-52. DOI: 10.1007/s00438-002-0772-4.

18. Chikmawati T, Skovmand B, Gust5afson JP. 2005. Phylogenetic relationships among Secale species revealed by amplified fragment length polymorphisms. Genome 48:792-801. DOI: $10.1139 / \mathrm{g} 05-043$. 
567 19. Cokus SJ, Feng S, Zhang X, Chen Z, Merriman B, Haudenschild CD, Pradhan S, Nelson SF,

568 Pellegrini M, Jacobsen SE. 2008. Shotgun bisulphite sequencing of the Arabidopsis genome 569 reveals DNA methylation patterning. Nature 452(7184): 215-219.

570 20. Cuadrado A, Jouve N. 2002. Evolutionary trends of different repetitive DNA sequences 571 during speciation in the genus Secale. The Journal of Heredity 93(5):339-345. 572 DOI: $10.1093 /$ jhered/93.5.339.

573 21. Darvey NL, Gustafson JP. 1975. Identification of rye chromosomes in wheta-rye addition 574 lines and triticale by heterochromatin bands. Crop Science 15:239-243. DOI: $575 \quad 10.2135 /$ cropsci1975.0011183X001500020029x.

576 22. De Bustos A, Jouve N. 2002. Phylogenetic relationships of the genus Secale based on the 577 characterisation of rDNA ITS sequences. Plant Systematics and Evolution 235(1):147-154. $578 \quad$ DOI: $10.1007 / \mathrm{s} 00606-002-0215-\mathrm{z}$.

579 23. Del Pozo JC, Figueiras AM, Benito C, De La Pelqa A. 1995. PCR derived molecular markers 580 and phylogenetic relationships in the Secale genus. Biologia Plantarum 37(4):481-489.

581 24. Eichten SR, Ellis NA, Makarevitch I, Yeh CT, Gent JI, Guo L, McGinnis KM, Zhang X, 582 Schnable PS, Vaughn MW, Dawe RK, Springer NM. 2012. Spreading of heterochromatin is 583 limited to specific families of maize retrotransposons. PLoS Genetics 8: e1003127. DOI: $584 \quad$ 10.1371/journal.pgen.1003127

585 25. Eichten SR, Briskine R, Song J, Li Q, Swanson-Wagner R, Hermanson PJ, Waters AJ, Starr 586 E, West PT, Tiffin P, Myers CL, Vaughn MW, Springer NM. 2013. Epigenetic and genetic 587 influences on DNA methylation variation in maize populations. Plant Cell 25:2783-2797. $588 \quad$ DOI: $10.1105 /$ tpc. 113.114793.

589 26. Eichten SR, Stuart T, Srivastava A, Lister R, Borevitz JO. 2016. DNA Methylation profiles 590 of diverse Brachypodium distachyon aligns with underlying genetic diversity. bioRxiv. 2016. 591 DOI: $10.1101 /$ gr.205468.116 biorxiv 
592 27. Fang J, Song C, Zheng Y, Qiao Y, Zhang Z, Dong Q, Chao CT. 2008. Variation in cytosine 593 methylation in Clementine mandarin cultivars. The Journal of Horticultural Science and 594 Biotechnology 83:833-839. DOI: 10.1080/14620316.2008.11512469.

595 28. Fang JG, Song CN, Qian JL, Zhang XY, Shangguan LF, Yu HP, Wang XC. 2010. Variation of 596 cytosine methylation in 57 sweet orange cultivars. Acta Physiologiae Plantarum 32:1023597 1030. DOI: $10.1007 / \mathrm{s} 11738-010-0491-0$.

598 29. Fedoroff N. 2012. Transposable elements, epigenetics, and genome evolution. Science $599 \quad 338: 758-767$. DOI: 10.1126/science.338.6108.758.

600 30. Federoff N. 2000. Transposons and genome evolution in plants. Proceedings of the National 601 Academy of Sciences of the United States of America 97:7002-7007. DOI: $602 \quad 10.1073 /$ pnas.97.13.7002

603 31. Feng S, Cokus SJ, Zhang X, Chen PY, Bostick M, Goll MG, Hetzel J, Jain J, Strauss 604 SH, Halpern ME, Ukomadu C, Sadler KC, Pradhan S, Pellegrini M, Jacobsen SE. 2010. 605 Conservation and divergence of methylation patterning in plants and animals. Proceedings of 606 the National Academy of Sciences of the United States of America 107:8689-8694. DOI: $607 \quad 10.1073 /$ pnas.1002720107.

608 32. Fernandez L, Torregrosa L, Segura V, Bouquet A, Martinez-Zapater JM. 2010. Transposon609 induced gene activation as a mechanism generating cluster shape somatic variation in 610 grapevine. Plant Journal 61:545-557. DOI: 10.1111/j.1365-313X.2009.04090.x.

611 33. Feschotte C, Pritham E. 2007. DNA transposons and the evolution of eukaryotic genomes. 612 The Annual Review of Genetics 41:331-368. DOI: 10.1146/annurev.genet.40.110405.090448. 613 34. Finnegan EJ, Kovac KA. 2000. Plant DNA methyltransferases. Plant Molecular Biology $614 \quad$ 43:189-210. DOI:10.1023/A:1006427226972 
615 35. Finnegan EJ, Genger RK, Peacock WJ, Dennis ES. 1998. DNA methylation in plants. Annual

616 Review of Plant Physiology and Plant Molecular Biology 49:223-247. DOI:

$617 \quad$ 10.1146/annurev.arplant.49.1.223

618 36. Flavell RB, Rimpau J, Smith DB. 1977. Repeated sequences DNA relationships in four cereal 619 genomes. Chromosoma 63:205-222. DOI:10.1007/BF00327450.

620 37. Fujimoto R, Kinoshita Y, Kawabe A, Kinoshita T, Takashima K, Nordborg M, Nasrallah ME, 621 Shmizu KK, Kudoh H, Kakutani T. 2008. Evolution and Control of Imprinted FWA Genes in 622 the Genus Arabidopsis. PLoS Genetetic 4(4):e1000048. DOI: 10.1371/journal.pgen.1000048.

623 38. Fujimoto R, Sugimura T, Fukai E, Nishio T. 2006. Suppression of gene expression of a 624 recessive SP11/SCR allele by an untranscribed SP11/SCR allele in Brassica self625 incompatibility. Plant Molecular Biology 61:577-587. DOI: 10.1007/s11103-006-0032-9.

626 39. Fulneček J, Matyasek R, Kovařík A. 2002. Distribution of 5-methylcytosine residues in 5S 627 rRNA genes in Arabidopsis thaliana and Secale cereale. Mol Gen Genomics 268(4):510-517.

628 40. Fulneček J, Kovařík A. 2014. How to interpret methylation sensitive amplified polymorphism 629 (MSAP) profiles? BMC Genetics 15:2.

630 41. González RM, Ricardi MM, Iusem ND. 2013. Epigenetic marks in an adaptive water stress631 responsive gene in tomato roots under normal and drought conditions. Epigenetics 8(8): 864632 872. DOI:10.4161/epi.25524.

633 42. Gorelick R. 2003. Evolution of dioecy and sex chromosomes via methylation driving Muller's 634 ratchet. The Biological Journal of the Linnean Society 80: 353-368. DOI: 10.1046/j.1095$635 \quad 8312.2003 .00244 . x$.

636 43. Grant-Downton RT, Dickinson HG. 2005. Epigenetics and its implications for plant biology.

637 1. The epigenetic network in plants. Annual Botany 96:1143-1164. DOI: 10.1093/aob/mci273. 
638 44. Grativol C, Hemerly AS, Gomes Ferreira PC. 2012. Genetic and epigenetic regulation of 639 stress responses in natural plant populations. Biochimica et Biophysica Acta 1819:176-185. 640 DOI: 10.1016/j.bbagrm.2011.08.010.

641 45. Grover C, Wendel J. 2010. Recent insights into mechanisms of genome size change in plants. 642 Journal of Botany 382732. DOI: 10.1155/2010/382732.

643 46. Hammer K. 1990. Breeding system and phylogenetic relationships in Secale. Biologisches 644 Zentralblatt 109(1):45-50.

645 47. Herrera CM, Bazaga P. 2011. Untangling individual variation in natural populations: 646 ecological, genetic and epigenetic correlates of long-term inequality in herbivory. Molecular 647 Ecology 20:1675-1688. DOI: 10.1111/j.1365-294X.2011.05026.x.

648 48. Hirochika H, Okamoto H, Kakutani T. 2000. Silencing of retrotransposons in Arabidopsis and 649 reactivation by the ddm1 mutation. Plant Cell 12:357-369. DOI: $10.1105 /$ tpc.12.3.357.

650 49. Hirsch S, Baumberger R, Grossniklaus U. 2013. Epigenetic variation, inheritance, and 651 selection in plant populations. Cold Spring Harbor Symposia on Quantitative Biology 77:97652 104. DOI: $10.1101 / \mathrm{sqb} .2013 .77 .014605$.

50. Hollister JD, Gaut BS. 2009. Epigenetic silencing of transposable elements: a trade-off 654 between reduced transposition and deleterious effects on neighboring gene expression. Genome Research 19:1419-1428. DOI: 10.1101/gr.091678.109.

51. Hollister JD, Smith LM, Guo Y-L, Ott F, Weigel D, Gaut BS. 2011. Transposable elements 657 and small RNAs contribute to gene expression divergence between Arabidopsis thaliana and 658 Arabidopsis lyrata. Proceedings of the National Academy of Sciences of the United States of 659 America 108:2322-2327. DOI: 10.1073/pnas.1018222108.

52. Jablonka E, Raz G. 2009. Transgenerational epigenetic inheritance: prevalence, mechanisms, 661 and implications for the study of heredity and evolution. The Quarterly Review of Biology 
663 53. Jaligot E, Beule T, Baurens FC, Billotte N, Rival A. 2004. Search for methylation-sensitive 664 amplification polymorphisms associated with the "mantled" variant phenotype in oil palm 665 (Elaeis guineensis Jacq.). Genome 47:224-228. DOI: 10.1139/g03-085.

666 54. Johannes F, Porcher E, Teixeira FK, Saliba-Colombani V, Simon M, Agier N, Bulski A, 667 Albuisson J, Heredia F, Audigier P, Bouchez D, Dillmann C, Guerche P, Hospital F, Colot V. 668 2009. Assessing the impact of transgenerational epigenetic variation on complex traits. PLoS 669 Genetics 5:e1000530. DOI: 10.1371/journal.pgen.1000530.

670 55. Johnson LM, Bostick M, Zhang X, Kraft E, Henderson I, Callis J, Jacobsen SE. 2007. The 671 SRA methyl-cytosine-binding domain links DNA and histone methylation. Curr Biol. 17(4): 672 379-384. DOI:10.1016/j.cub.2007.01.009.

56. Kakutani T. 2002. Epi-alleles in plants: inheritance of epigenetic information over 674 generations. Plant Cell Physiology 43:1106-1111. DOI: 10.1093/pcp/pcf131.

675 57. Kalisz S, Purugganan MD. 2004. Epialleles via DNA methylation: Consequences for plant 676 evolution. Trends in Ecology and Evolution 9(6):309-314. DOI: 10.1016/j.tree.2004.03.

$677 \quad 034$.

678 58. Kankel MW, Ramsey DE, Stokes TL, Flowers SK, Haag JR, Jeddeloh JA, Riddle NC, 679 Verbsky ML, Richards EJ. 2003. Arabidopsis MET1 cytosine methyltransferase mutants. 680 Genetics 163:1109-1122.

59. Kato M, Miura A, Bender J, Jacobsen SE, Kakutani T. 2003. Role of CG and non-CG 682 methylation in immobilization of transposons in Arabidopsis. Current Biology 13, 421-426. DOI: $10.1016 / \mathrm{S} 0960-9822(03) 00106-4$.

60. Kawanabe T, Fujimoto R, Sasaki T, Taylor J, Dennis ES. 2012. A comparison of 685 transcriptome and epigenetic status between closely related species in the genus Arabidopsis. 686 Gene 506(2):301-309. DOI: 10.1016/j.gene.2012.07.003. 
687 61. Kim MY, Zilberman D. 2014. DNA methylation as a system of plant genomic immunity. 688 Trends Plant Science 19(5):320-326. DOI: 10.1016/j.tplants.2014.01.014.

689

690

691

692

693

694

695

696

697

698

699

700

701

702

703

704

705

706

707

708

709

710

62. Kim DY, Han YJ, Kim S, Song JT, Seo HS. 2015. Arabidopsis CMT3 activity is positively regulated by AtSIZ1-mediatedsumoylation. Plant Science 239:209-215. DOI: 10.1016/j.plantsci.2015.08.003.

63. Leitch I, Leitch A. 2013. Genome size diversity and evolution in land plants. In: Greilhuber J, Dolezel J, Wendel JF, ed. Plant genome diversity. Volume 2. Physical structure, behaviour and evolution of plant genomes. New York: Springer, 307-322.

64. Li X, Wang X, He K, Ma Y, Su N, He H, Stolc V, Tongprasit W, Jin W, Jiang J, Terzaghi W, Li S, Deng XW. 2008. High-resolution mapping of epigenetic modifications of the rice genome uncovers interplay between DNA methylation, histone methylation, and gene expression. Plant Cell 20(2):259-276. DOI:10.1105/tpc.107.056879.

65. Li XL, Lin ZX, Nie YC, Guo XP, Zhang XL. 2009. Methylation-sensitive amplification polymorphism of epigenetic changes in cotton under salt stress. Acta Agronomica Sinica 35:588-596. DOI: 10.1007/s13258-015-0301-6.

66. Li Q, Gent JI, Zynda G, Song J, Makarevitch I, Hirsch CD, Hirsch CN, Dawe RK, Madzima TF, McGinnis KM, Lisch D, Schmitz RJ, Vaughn MW, Springer NM. 2015. RNA-directed DNA methylation enforces boundaries between heterochromatin and euchromatin in the maize genome. Proceedings of the National Academy of Sciences of the United States of America 112:14728-14733. DOI: 10.1073/pnas.1514680112.

67. Lippman Z, Gendrel AV, Black M, Vaughn MW, Dedhia N, McCombie WR, Lavine K, Mittal V, May B, Kasschau KD, Carrington JC, Doerge RW, Colot V, Martienssen R. 2004. Role of transposable elements in heterochromatin and epigenetic control. Nature 430:471-476. DOI: 10.1038/nature02651. 
711 68. Mcclintock B. 1984. The significance of responses of the genome to challenge. Science 712 226:792-801. DOI: 10.1126/science 15739260.

713 69. Merker A. 1976.The cytogenetic effect of heterochromatin in hexaploid triticale. Hereditas $714 \quad 83: 215$ - 222. DOI: 10.1111/j.1601-5223.1976.tb01586.x.

715 70. Meyer T. 2010. DNA methylation systems and targets in plants. FEBS Letters 13:2008-2015. 716 DOI: 10.1016/j.febslet.2010.08.017.

717 71. Meyer P. 2011. DNA methylation systems and targets in plants. FEBS Letters 58(13): 20082015.

719 72. Mirouze M, Vitte C. 2014. Transposable elements, a treasure trove to decipher epigenetic 720 variation: insights from Arabidopsis and crop epigenomes. Journal of Experimental Botany $721 \quad$ 65:2801-12. DOI: 10.1093/jxb/eru120.

722 73. Murai K, Naiyu X, Tsunewaki K. 1989. Studies on the origin of crop species by restriction 723 endonuclease analysis of organellar DNA. III. Chloroplast DNA variation and interspecific 724 relationships in the genus Secale. Japanese Journal of Genetics 4:35-47. DOI: $725 \quad 10.1266 /$ jjg.64.35.

726 74. Nachman M, Crowell S. 2000. Estimate of the mutation rate per nucleotide in humans. $727 \quad$ Genetics 156:297-304.

728 75. Naito K, Zhang F, Tsukiyama T, Saito H, Hancock CN, Richardson AO, Okumoto Y, Tanisaka 729 T, Wessler SR. 2009. Unexpected consequences of a sudden and massive transposon 730 amplification on rice gene expression. Nature 461:1130-34. DOI: 10.1038/nature08479.

731 76. Nei M, Li WH. 1979. Mathematical model for studying genetic variation in terms of 732 restriction endonucleases. Proceedings of the National Academy of Sciences of the United 733 States of America 76(10):5269-5273. 
734 77. Osabe K, Clement JD, Bedon F, Pettolino FA, Zielkowski L, Llewellyn DJ, Finnegan EJ, 735 Wilson IW. 2014. Genetic and DNA methylation changes in cotton (Gossypium) genotypes 736 and tissues. PLoS One 9,e86049. DOI: 10.1371/journal.pone.0086049.

737 78. Ossowski S, Schneeberger K, Lucas-Lledo J, Warthmann N, Clark R, Shaw R, Weigel D, 738 Lynch M. 2010. The rate and molecular spectrum of spontaneous mutations in Arabidopsis 739 thaliana. Science 327:92-94. DOI: 10.1126/science.1180677.

740 79. Page RDM. 1996. TreeView: An application to display phylogenetic trees on personal 741 computers. Computer Applications in the Biosciences 12(4):357-358.

742 80. Pavlícek A, Hrdá Š, Flegr J. 1999. FreeTree - freeware program for construction of 743 phylogenetic trees on the basis of distance data and for bootstrap/jackknife analysis of the 744 trees robustness. Application in the RAPD analysis of genus Frenkelia. Folia Biologica (Praha) $745 \quad 45: 97-99$.

746 81. Pearce SR, Pich U, Harrison G, Flavell AJ, Heslop-Harrison JS, Schubert I, Kumar A. 1996. 747 The Tyl-copia group retrotransposons of Allium cepa are distributed throughout the 748 chromosomes but are enriched in the terminal heterochromatin. Chromosome Research 4:357364. DOI: 10.1007/BF02257271.

82. Petersen G, Doebley JF. 1993. Chloroplast DNA variation in the genus Secale (Poaceae). Plant Systematics and Evolution 187(1-4):115-125. DOI: 10.1007/BF00994094.

83. Ren TH, Chen F, Zou YT, Jia YH, Zhang HQ, Yan BJ, Ren ZL. 2011. Evolutionary trends of 753 microsatellites during the speciation process and phylogenetic relationships within the genus 754 Secale. Genome 54:316-326. DOI: 10.1139/g10-121.

755 84. Rozhon W, Baubec T, Mayerhofer J, Scheid O, Jonak C. 2008. Rapid quantification of global 756 DNA methylation by isocratic cation exchange high performance liquid chromatography. 757 Analytical Biochemistry 375:354-360. DOI: 10.1016/j.ab.2008.01.001. 
758 85. Róis AS, López CMR, Cortinhas A, Erben M, Espírito-Santo D, Wilkinson MJ, Caperta AD.

759 2013. Epigenetic rather than genetic factors may explain phenotypic divergence between 760 coastal populations of diploid and tetraploid Limonium spp. (Plumbaginaceae) in Portugal. 761 BMC Plant Biology. 13:205. DOI:10.1186/1471-2229-13-205.

762 86. Salmon A, Clotault J, Jenczewski E, Chable V, Manzanares-Dauleux MJ. 2008. Brassica 763 oleracea displays a high level of DNA methylation polymorphism. Plant Science 174: 61-70. $764 \quad$ DOI: 10.1016/j.plantsci.2007.09.012.

765 87. Sano H, Kamada I, Youssefian S, Katsumi M, Wabiko H. 1990. A single treatment of rice 766 seedlings with 5-azacytidine induces heritable dwarfism and undermethylation of genomic 767 DNA. Molecular Genetics and Genomics 220:441-447. DOI: 10.1007/BF00391751.

768 88. Sasaki T, Fujimoto R, Kishitani S, Nishio T. 2011. Analysis of target sequences of DDM1s 769 in Brassica rapa by MSAP. Plant Cell Reports 30:81-88. DOI: 10.1007/s00299-010-0946-1.

89. Saze H, Kakutani T. 2007. Heritable epigenetic mutation of a transposon-flanked Arabidopsis 771 gene due to lack of the chromatin-remodeling factor DDM1. The EMBO Journal 26:36413652. DOI: 10.1038/sj.emboj.7601788.

90. Schulman AH, Flavell AJ, Ellis TH. 2004. The application of LTR retrotransposons as 774 molecular markers in plants. Methods in Molecular Biology 260:145-173. DOI: 10.1385/1$775 \quad 59259-755-6: 145$.

776 91. Sae-Eung C, Kanchanaketu T, Sangduen N, Hongtrakul V. 2012. DNA methylation and 777 genetic diversity analysis of genus Cycas in Thailand. African Journal of Biotechnology 11(4): 743-751. DOI: 10.5897/AJB11.2835. hybridization and allopolyploidy in wheat. Plant Cell. 13(8):1749-59. 
782 93. Shang HY, Wei YM, Wang XR, Zheng YL. 2006. Genetic diversity and phylogenetic 783 relationships in the rye genus Secale L. (rye) based on Secale cereale microsatellite markers. 784 Genetics and Molecular Biology 29(4): 685-691. DOI: 10.1590/S1415-47572006000400018.

785

786

787

788

789

790

791

792

793

794

795

796

797

798

799

800

801

802

803

804

805

94. Singh RJ, Röbbelen G. 1977. Identification by Giemsa technique of the translocations separating cultivated rye from three wild species of Secale. Chromosoma 59:217-229. DOI: 10.1007/BF00292779.

95. Soppe, WJJ, Jasencakova, Z, Houben, A, Kakutani, T, Meister, A, Huang, MS, Jacobsen, SE, Schubert, I, Fransz, PF. 2002. DNA methylation controls histone H3 lysine 9 methylation and heterochromatin assembly in Arabidopsis. EMBOJ 21:6549-6559.

96. Steward N, Ito M, Yamaguchi Y, Koizumi N, Sano H. 2002. Periodic DNA methylation in maize nucleosomes and demethylation by environmental stress. Journal of Biological Chemistry 277:37741-37746. DOI: 10.1074/jbc.M204050200.

97. Tarkowski C. 1983. Biology of rye. PWN Warsaw [in polish].

98. Tsukahara S, Kobayashi A, Kawabe A, Mathieu O, Miura A, Kakutani T. 2009. Bursts of retrotransposition reproduced in Arabidopsis. Nature 461:423-426. DOI: $10.1038 /$ nature 08351 .

99. Venetsky A, Levy-Zamir A, Khasdan V, Domb K, Kashkush K. 2015. Structure and extent of DNA methylation-based epigenetic variation in wild emmer wheat ( $T$. turgidum ssp. dicoccoides) populations. BMC Plant Biology 15:200. DOI: 10.1186/s12870-015-0544-z

100. Vergeer P, Wagemaker N, Ouborg N. 2012. Evidence for an epigenetic role in inbreeding depression. Biology Letters 8:798-801. DOI: 10.1098/rsbl.2012.0494.

101. Verhoeven KJF, Jansen JJ, van Dijk PJ, Biere A. 2010. Stress-induced DNA methylation changes and their heritability in asexual dandelions. New Phytologist 185:1108-1118. DOI: 10.1111/j.1469-8137.2009.03121.x. 
806 102. Vicient CM, Jaaskelainen MJ, Kalendar R, Schulman AH. 2001. Active retrotransposons 807 are a common feature of grass genomes. Plant Physiology 125:1283-1292. DOI: 10.1104/pp. $808 \quad 125.3 .1283$.

809 103. Wang J, Chen S, Qi X, Fang W, Guan Z, Teng N, Liao Y, Chen F. 2014. Rapid genetic and 810 epigenetic alterations under intergeneric genomic shock in newly synthesized Chrysanthemum 811 morifolium $\mathrm{x}$ Leucanthemum paludosum hybrids (Asteraceae). Genome Biology and 812 Evolution 6:247-259. DOI: 10.1093/gbe/evu008.

813 104. Yang L, Gaut BS. 2011. Factors that contribute to variation in evolutionary rate among 814 Arabidopsis genes. Molecular Biology and Evolution 28:2359-2369. DOI: $815 \quad 10.1093 / \mathrm{molbev} / \mathrm{msr} 058$.

816 105. Zhou JP, Yang ZJ, Li GR, Liu C, Tang ZX, Zhang Y, Ren ZL. 2010. Diversified 817 chromosomal distribution of tandemly repeated sequences revealed evolutionary trends in 818 Secale (Poaceae). Plant Systematics and Evolution 287(1-2):49-56. DOI: 10.1007/s00606$819 \quad 010-0288-z$.

820106. Zilberman D, Gehring M, Tran RK, Ballinger T, Henikoff S. 2007. Genome-wide analysis of 821 Arabidopsis thaliana DNA methylation uncovers an interdependence between methylation and 822 transcription. Nature Genetics 39:61-69. DOI: 10.1038/ng1929. 


\section{Table $\mathbf{1}$ (on next page)}

Table 1. The sequences of the oligonucleotides used in this study and the combinations of selective primers. 


\begin{tabular}{|c|c|c|}
\hline Type & Name/combination & Sequences \\
\hline \multirow[t]{2}{*}{ Adapters } & Eco adapter & $\begin{array}{l}\text { 5'- CTCGTAGACTGCGTACC and } \\
\text { 5'- AATTGGTACGCAGTCTAC }\end{array}$ \\
\hline & Hpa/Msp adapter & $\begin{array}{l}\text { 5'- GATCATGAGTCCTGCT and } \\
\text { 5'- CGAGCAGGACTCATGA }\end{array}$ \\
\hline \multirow{3}{*}{$\begin{array}{l}\text { Preselective } \\
\text { primers }\end{array}$} & $\mathrm{Eco}+\mathrm{A}$ & 5'- GACTGCGTACCAATTCA \\
\hline & $\mathrm{Hpa}+\mathrm{A}$ & 5'- ATCATGAGTCCTGCTCGGA \\
\hline & $\mathrm{Hpa}+\mathrm{C}$ & 5'- ATCATGAGTCCTGCTCGGC \\
\hline \multirow[t]{9}{*}{ Selective primers } & Eco+AC & 5'- GACTGCGTACCAATTCAC \\
\hline & $\mathrm{Eco}+\mathrm{AG}$ & 5'- GACTGCGTACCAATTCAG \\
\hline & $\mathrm{Hpa}+\mathrm{ATG}$ & 5'- ATCATGAGTCCTGCTCGGATG \\
\hline & $\mathrm{Hpa}+\mathrm{ATT}$ & 5'-ATCATGAGTCCTGCTCGGATT \\
\hline & $\mathrm{Hpa}+\mathrm{ACC}$ & 5'- ATCATGAGTCCTGCTCGGACC \\
\hline & $\mathrm{Hpa}+\mathrm{ACG}$ & 5'- ATCATGAGTCCTGCTCGGACG \\
\hline & $\mathrm{Hpa}+\mathrm{AAG}$ & 5'- ATCATGAGTCCTGCTCGGAAG \\
\hline & $\mathrm{Hpa}+\mathrm{CTT}$ & 5'- ATCATGAGTCCTGCTCGGCTT \\
\hline & $\mathrm{Hpa}+\mathrm{CGC}$ & 5'- ATCATGAGTCCTGCTCGGCGC \\
\hline $\begin{array}{l}\text { Selective primers } \\
\text { pairs }\end{array}$ & \multicolumn{2}{|c|}{$\begin{array}{l}\text { Eco }+ \text { AC and } \mathrm{Hpa}+\mathrm{ATG} ; \mathrm{Eco}+\mathrm{AG} \text { and } \mathrm{Hpa}+\mathrm{ATG} ; \mathrm{Eco}+\mathrm{AC} \text { and } \mathrm{Hpa}+\mathrm{ATT} ; \mathrm{Eco}+\mathrm{AC} \text { and } \mathrm{Hpa}+\mathrm{ACC} ; \\
\text { Eco }+\mathrm{AC} \text { and } \mathrm{Hpa}+\mathrm{ACG} ; \mathrm{Eco}+\mathrm{AC} \text { and } \mathrm{Hpa}+\mathrm{AAG} ; \mathrm{Eco}+\mathrm{AG} \text { and } \mathrm{Hpa}+\mathrm{CTT} ; \text { Eco }+\mathrm{AC} \text { and } \mathrm{Hpa}+\mathrm{CGC} ; \\
\text { Eco }+\mathrm{AC} \text { and } \mathrm{Hpa}+\mathrm{CTT}\end{array}$} \\
\hline
\end{tabular}

2 


\section{Table 2 (on next page)}

Table 2. The methylation status of the 5'-CCGG-3' sequence base on the presence (1) or absense (0) of DNA restriction fragments (Hpall and Mspl). C - unmethylated cytosine, ${ }^{\mathrm{m} C}$ - methylated cytosine. 


\begin{tabular}{|c|c|c|c|c|c|c|c|}
\hline & & & & & & HpaII & MspI \\
\hline $\begin{array}{l}\mathrm{C} \\
\mathrm{G}\end{array}$ & $\begin{array}{l}\mathrm{C} \\
\mathrm{G}\end{array}$ & $\begin{array}{l}\mathrm{G} \\
\mathrm{C}\end{array}$ & $\begin{array}{l}\mathrm{G} \\
\mathrm{C}\end{array}$ & type 11 & unmethylated & 1 & 1 \\
\hline $\begin{array}{l}\mathrm{C} \\
\mathrm{G}\end{array}$ & $\begin{array}{c}{ }^{\mathrm{m}} \mathrm{C} \\
\mathrm{G}\end{array}$ & $\begin{array}{c}\mathrm{G} \\
{ }^{\mathrm{m}} \mathrm{C}\end{array}$ & $\begin{array}{l}\mathrm{G} \\
\mathrm{C}\end{array}$ & type 01 & internal cytosine methylation & 0 & 1 \\
\hline${ }^{\mathrm{m}} \mathrm{C}$ & ${ }^{\mathrm{m}} \mathrm{C}$ & $\mathrm{G}$ & $\mathrm{G}$ & & & & \\
\hline G & $\mathrm{G}$ & $\mathrm{C}$ & $\mathrm{C}$ & & & & \\
\hline & & & & type 10 & hemimethylated & 1 & 0 \\
\hline $\begin{array}{c}{ }^{\mathrm{m}} \mathrm{C} \\
\mathrm{G}\end{array}$ & $\begin{array}{l}\mathrm{C} \\
\mathrm{G}\end{array}$ & $\begin{array}{l}\mathrm{G} \\
\mathrm{C}\end{array}$ & $\begin{array}{l}\mathrm{G} \\
\mathrm{C}\end{array}$ & & & & \\
\hline $\begin{array}{r}{ }^{\mathrm{m}} \mathrm{C} \\
\mathrm{G}\end{array}$ & $\begin{array}{c}{ }^{\mathrm{m}} \mathrm{C} \\
\mathrm{G}\end{array}$ & $\begin{array}{c}\mathrm{G} \\
{ }^{\mathrm{m}} \mathrm{C}\end{array}$ & $\begin{array}{c}\mathrm{G} \\
{ }^{\mathrm{m}} \mathrm{C}\end{array}$ & type 00 & full methylation & 0 & 0 \\
\hline
\end{tabular}

2

3

4

5 


\section{Table 3(on next page)}

Table 3. The upper part of the table (grey cells) contains Dice coefficients (reflecting the epigenetic similarity among the rye taxons); the lower part (blue cells) contains the $\mathrm{U}$ values (showing the differences between the rye taxons); both sets of $d$ 


\begin{tabular}{|c|c|c|c|c|c|c|c|c|}
\hline & $\begin{array}{c}\tilde{\Xi} \\
-\tilde{\Xi} \\
\tilde{\Xi} \\
0 \\
0 \\
0 \\
0 \\
0 \\
0 \\
ن \\
ن \\
\dot{\omega}\end{array}$ & 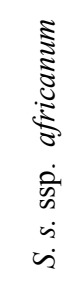 & $\begin{array}{c}\tilde{\Xi} \\
\tilde{J} \\
\tilde{u} \\
\dot{v} \\
\dot{s}\end{array}$ & 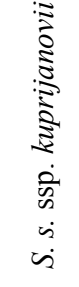 & 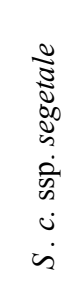 & 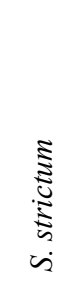 & 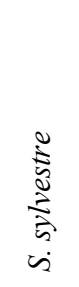 & 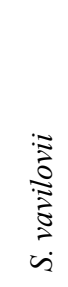 \\
\hline S. c. ssp. afganicum & & 0,95 & 0,95 & 0,96 & 0,94 & 0,95 & 0,90 & 0,93 \\
\hline S. s. ssp. africanum & 0.35 & & 0,92 & 0,92 & 0,90 & 0,93 & 0,88 & 0,93 \\
\hline S. cereale & 0.54 & 0.89 & & 0,96 & 0,96 & 0,94 & 0,91 & 0,95 \\
\hline S. s. ssp. kuprijanovii & 0.36 & 0.71 & 0.18 & & 0,96 & 0,95 & 0,87 & 0,92 \\
\hline S. c. ssp. segetale & 0.90 & 1.25 & 0.36 & 0.54 & & 0,95 & 0,88 & 0,91 \\
\hline S. strictum & 0.18 & 0.53 & 0.36 & 0.18 & 0.72 & & 0,88 & 0,89 \\
\hline S. sylvestre & 0.54 & 0.89 & 0.00 & 0.18 & 0.36 & 0.36 & & 0,92 \\
\hline S. vavilovii & 0.54 & 0.89 & 0.00 & 0.18 & 0.36 & 0.36 & 0.00 & \\
\hline
\end{tabular}

2

3

4

5

6

7

8

9

10

11

12

13 


\section{Table 4 (on next page)}

Table 4. The upper part of the table (grey cells) contains $P$ values from Kruskal-Wallis test for the differences in total t-heterochromatin content among the genomes of rye taxons; the lower part (blue cells) contains P values from Tukey test for the dif 


\begin{tabular}{|c|c|c|c|c|c|c|c|c|}
\hline & 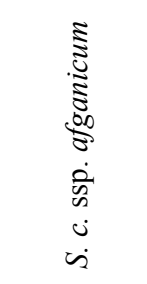 & 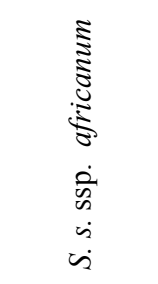 & 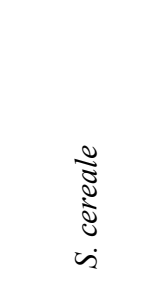 & 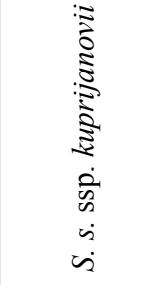 & 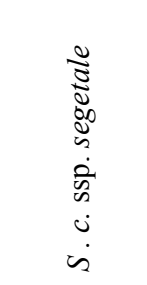 & 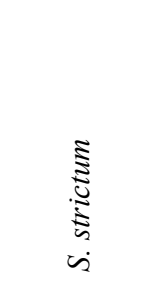 & 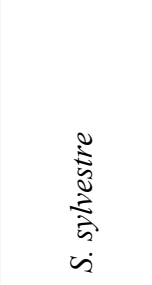 & 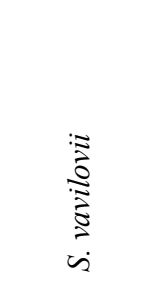 \\
\hline S. c. ssp. afganicum & & $0,000032 *$ & 1,000000 & 0,331233 & 1,000000 & $0,007999 *$ & $0,000004^{*}$ & 0,132453 \\
\hline S. s. ssp. africanum & 0,934268 & & $0,000000^{*}$ & 0,526546 & $0,000016^{*}$ & 1,000000 & 1,000000 & $0,000000^{*}$ \\
\hline S. cereale & 0,951740 & 1,000000 & & $0,002697^{*}$ & 1,000000 & $0,000015^{*}$ & $0,000000^{*}$ & 1,000000 \\
\hline S. s. ssp. kuprijanovii & 0,633481 & 0,998885 & 0,997694 & & 0,226022 & 1,000000 & 0,175761 & $0,000003 *$ \\
\hline S. c. ssp. segetale & 0,456476 & $0,035269 *$ & $0,042688^{*}$ & $0,005712 *$ & & $0,004762 *$ & $0,000002 *$ & 0,198283 \\
\hline S. strictum & $0,000137 *$ & $0,002251^{*}$ & $0,001789^{*}$ & $0,015542 *$ & $0,000118^{*}$ & & 1,000000 & $0,000000^{*}$ \\
\hline S. sylvestre & $0,035658^{*}$ & 0,459018 & 0,414978 & 0,832923 & $0,000138^{*}$ & 0,444195 & & $0,000000^{*}$ \\
\hline S. vavilovii & 0,530631 & 0,995110 & 0,991593 & 1,000000 & $0,003448 *$ & $0,024517^{*}$ & 0,899162 & \\
\hline
\end{tabular}

2 


\section{Figure 1}

Methylation level (\%) of Methylation-Susceptible Loci (MSL) in Secale taxons.

Type 1 - unmethylated, type 2 - internal cytosine methylation, type 3 - hemimethylated, type 4 - full methylation.

*Note: Auto Gamma Correction was used for the image. This only affects the reviewing manuscript. See original source image if needed for review.

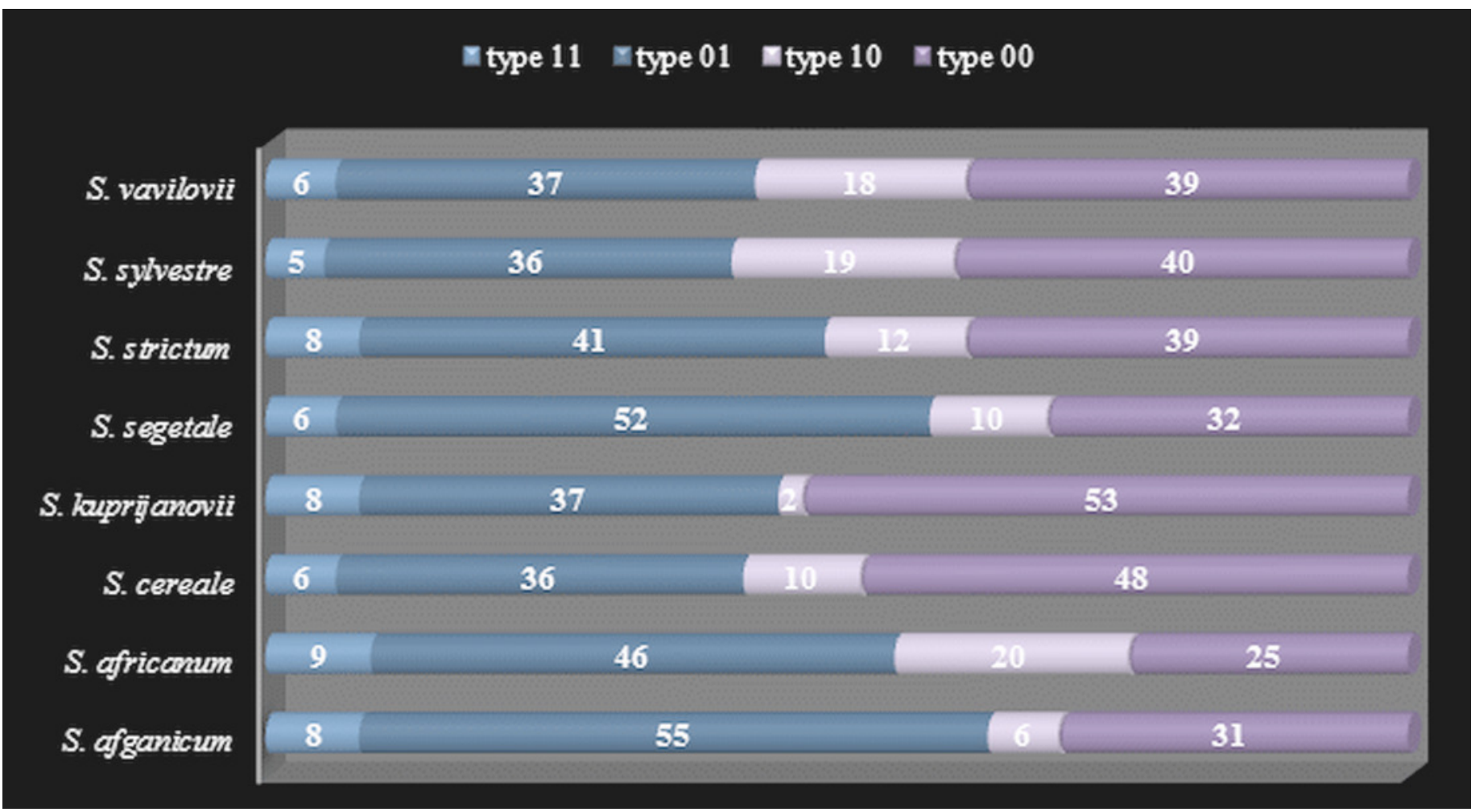




\section{Figure 2}

Principal Coordinate Analyses for epigenetic differentiation between the groups and Neighbor-Joining tree for epigenetic distances.

Principal Coordinate Analyses (PCOA) for epigenetic (MSL) differentiation between Secale taxons (A) and Secale species (B); (C): Neighbor-Joining tree of Secale species for epigenetic (MSL) distances; colors represent different taxons/species; (A), (B): C1 and C2 coordinates are shown with the percentage of variance explained by them, in (B) different point types represent subspecies from different species, species labels show the centroid for the points cloud in each species, ellipses represent the average dispersion of those points around their center, the long axis of the ellipse shows the direction of maximum dispersion and the short axis, the direction of minimum dispersion; cereale: S. cereale, S. c. ssp. afghanicum, S. c. ssp. segetale; strictum: S. strictum, S. s. ssp. africanum, S. s. ssp. kuprijanovii; sylvestre: S. sylvestre; vavilovii: S. vavilovii 
$\mathbf{A}$

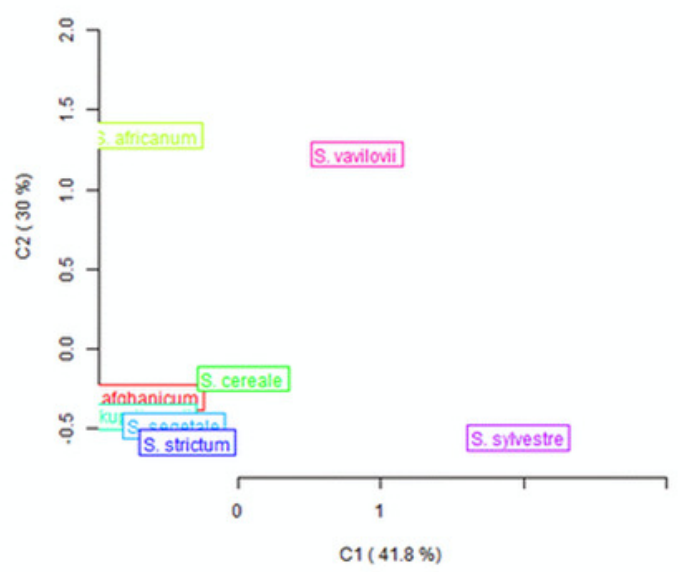

B

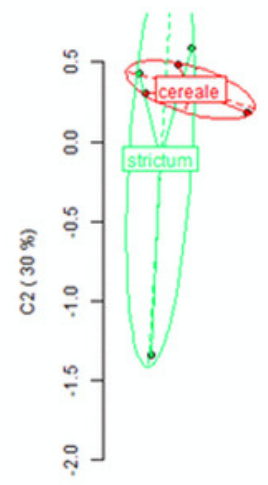

vavilovii

C

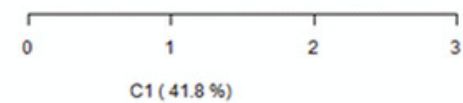

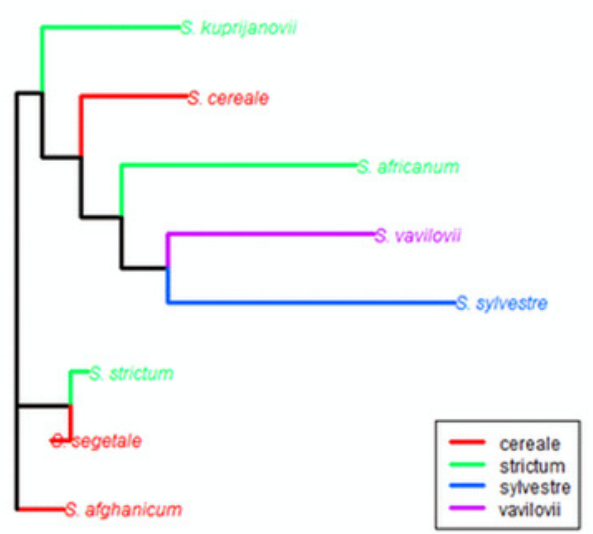


Figure 3

UPGMA dendrogram representing epigenetic relationships among rye taxons based on the data from MSAP analysis.

The numbers represent bootstrapping values.

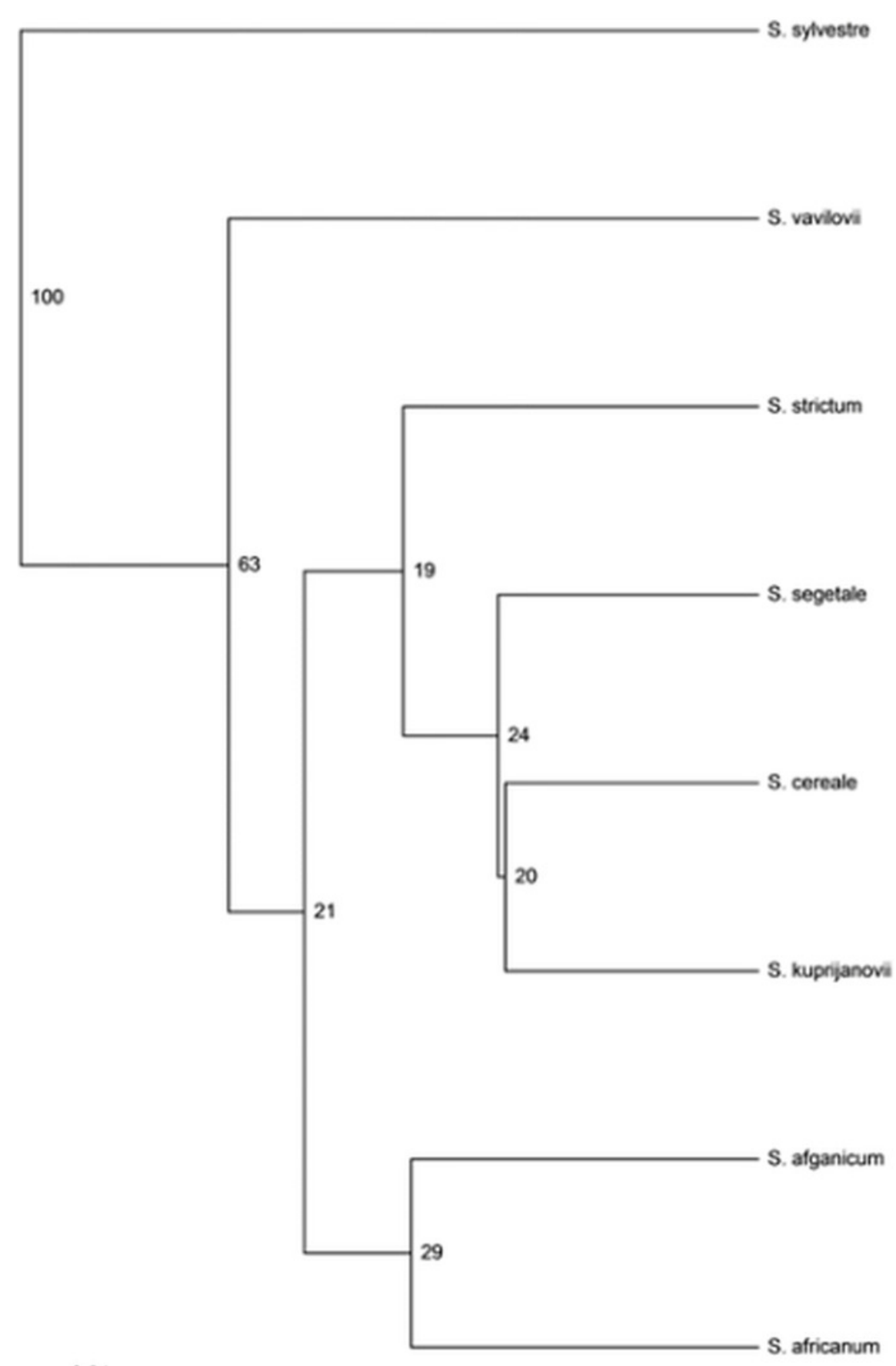




\section{Figure 4}

The comparison of t-heterochromatin content and cytosine methylation.

Total telomeric heterochromatin content (\%) in rye genomes, level (\%) of cytosine methylation at CCGG sites from MSAP analysis, and global cytosine methylation (\%) from ELISA analysis.

n telomeric heterochromatin content (\%) m methylated CCGG sites (\%) m global cytosine methylation (\%)
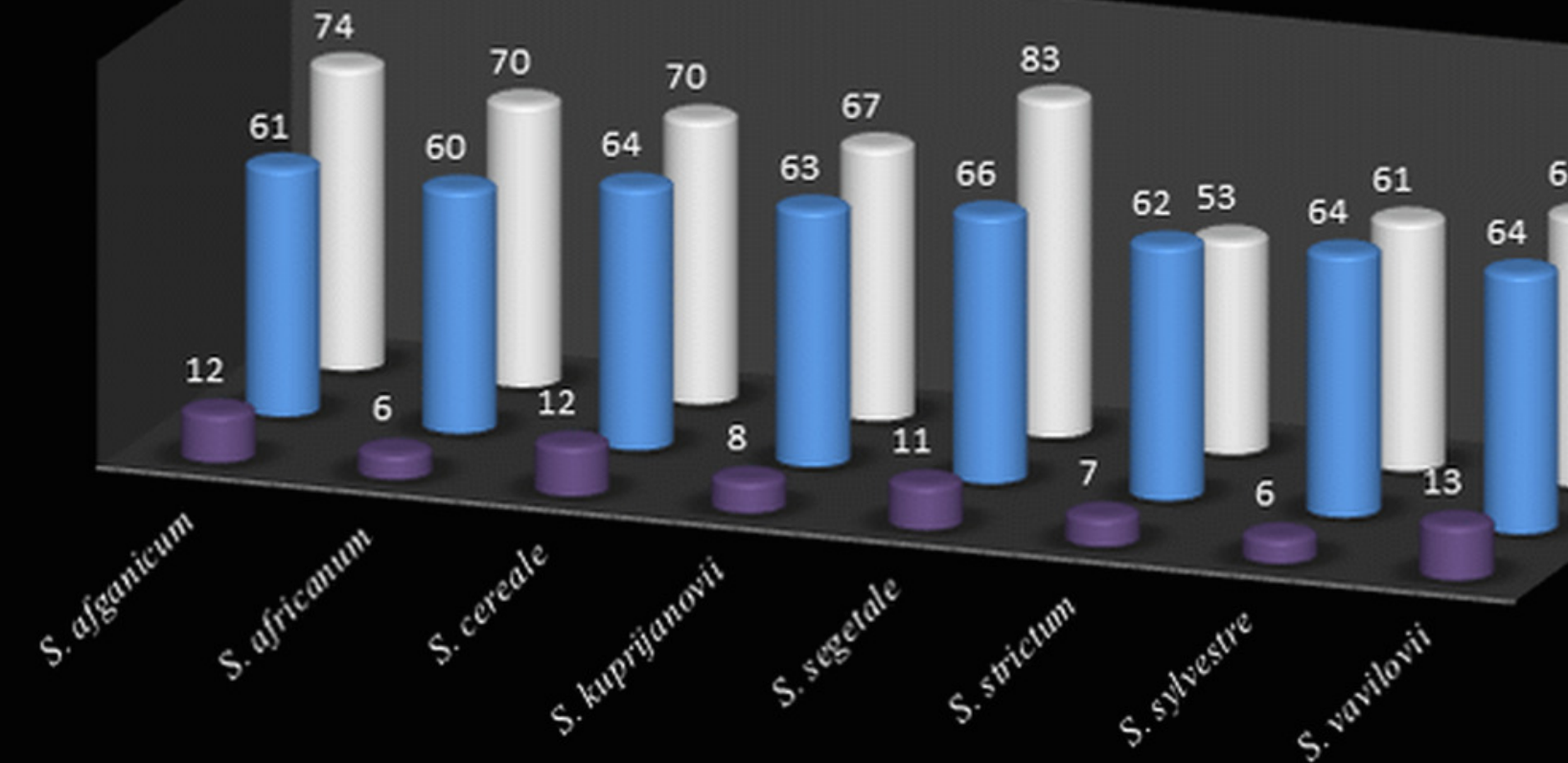


\section{Figure 5}

2C DNA nuclear content (pg).

* The $2 \mathrm{C}$ value for Secale cereale was used as reference value.

*Note: Auto Gamma Correction was used for the image. This only affects the reviewing manuscript. See original source image if needed for review.

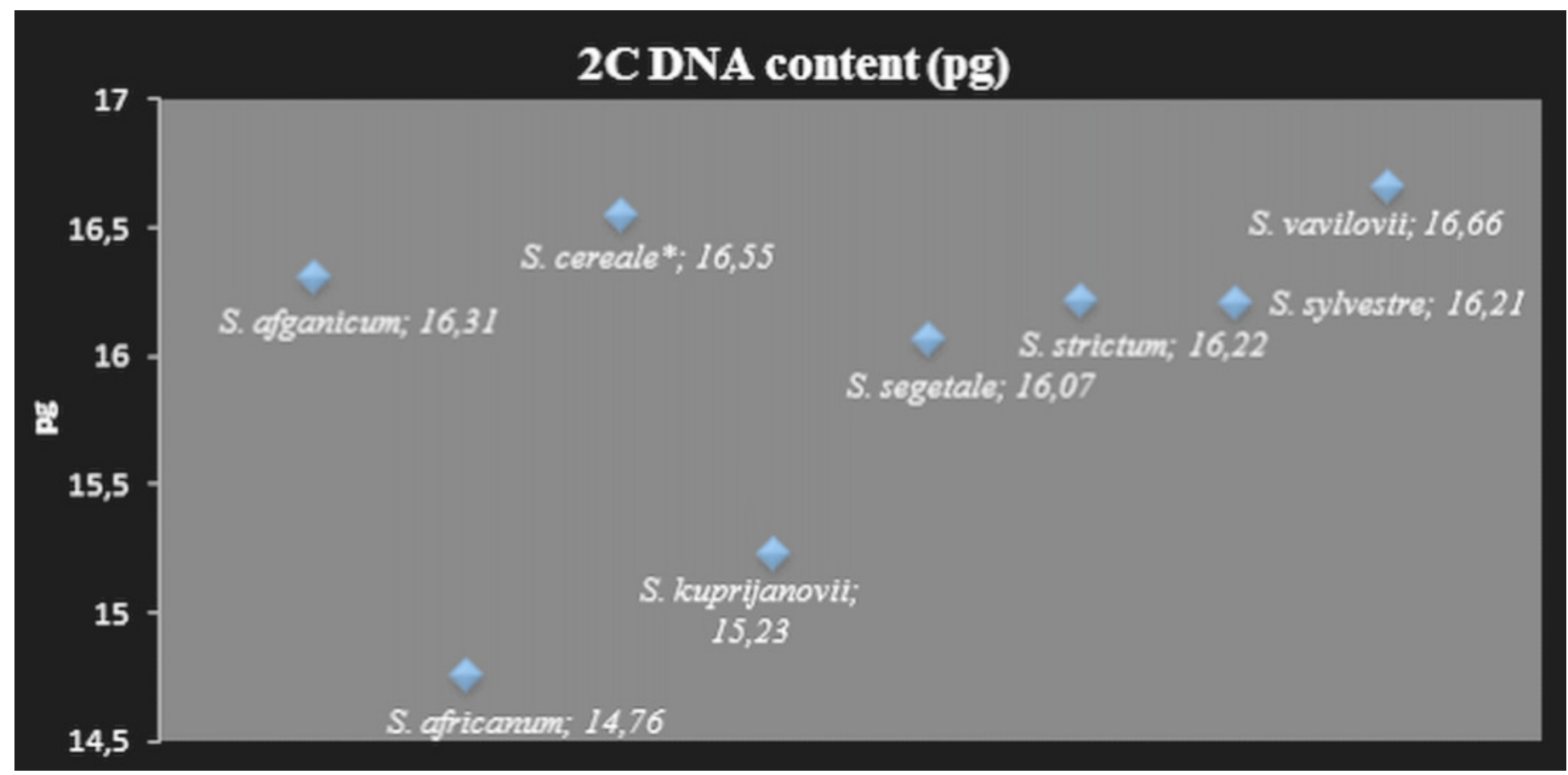




\section{Figure 6}

C-banded methaphase chromosomes of Secale, A: Secale vavilovii, B: Secale sylvestre.
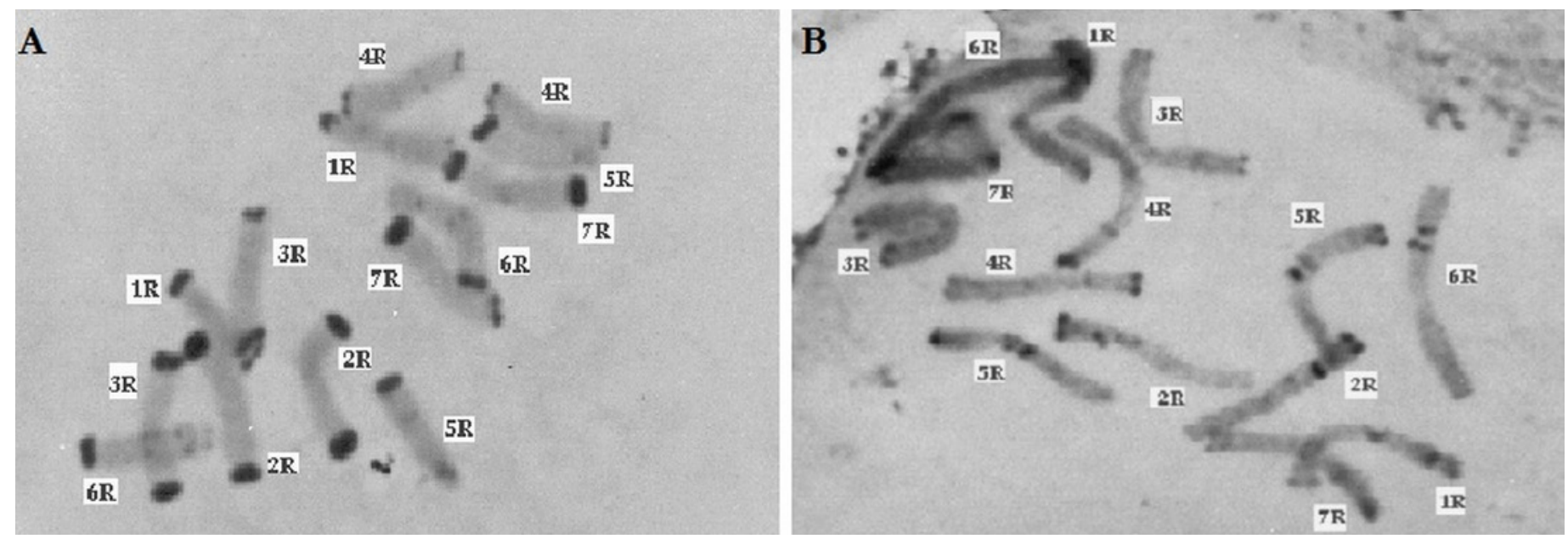